\title{
The Sustainability of Plastic Nets in Agriculture
}

\author{
Chrysanthos Maraveas (D) \\ Department of Civil Engineering, University of Patras, 26504 Rio, Greece; c.maraveas@maraveas.gr
}

Received: 25 March 2020; Accepted: 28 April 2020; Published: 30 April 2020

\begin{abstract}
This review article contributes new knowledge relating to the sustainability of antihail, anti-insect, and windbreak plastic nets in agriculture. Based on the review, biobased plastic nets made from polyamino acids, polysaccharide derivatives (DS), polyhydroxybutyrate (PHB), polycaprolactone (PCL), polyhydroxylalkanoate (PHA), and polylactic acid (PLA) are shown to be highly biodegradable compared to conventional plastics such as high-density polyethylene (HDPE), polyethylene (PE), and polyvinyl chloride. The biodegradability of these materials is due to the use of natural precursors. However, nonbiodegradable plastics are the materials of choice in agricultural applications for the following reasons. Global commercial production of biobased plastics is low $(\sim 1 \%)$ due to the absence of facile and scalable production methods. Even though biobased materials are ecologically benign, they are limited in agricultural settings, given the low tensile strength and disruption of the activities of natural insect predators such as spiders. The enhancement of the material properties of biobased plastics involves a trade-off with sustainability. Chemical additives such as heavy metals and volatile compounds enhance the mechanical properties of biobased plastics but limit their sustainability. The current constraints on the production of biobased plastic nets can be resolved through electrospinning techniques that facilitate the development of plastic nets with controllable composition, porosity, and surface areas.
\end{abstract}

Keywords: plastic nets; sustainability; agriculture (polymers; biodegradability; compost; pests; soil

\section{Introduction}

This review article investigates the sustainability of plastic nets used in agricultural applications. The review focuses on the following areas: the sustainability of plastic nets in agricultural settings, mechanical properties, biobased plastic nets, novel synthetic routes, the impact of plastic nets on non-biodegradable waste stock, and farming. The use of polymer materials in agricultural applications raises concerns due to the adoption of new environmental regulations, ecological awareness about climate change, and social concerns about pollution [1]. From a food security point of view, plastic nets, especially those that are capable of protecting plants from insects, hail, and wind, are critical to the availability of agricultural produce, whose demand is expected to surge over time due to global population growth [2].

There are specific agricultural benefits attributed to the application of plastic nets, such as reduced pests and insects and the utilization of pesticides [3]. So far, plastic nets have proven useful in the control of Xylella fastidiosa and Philaenus spumarius - pests that are common in orchards and olive tree nurseries [4]. Apart from the control of pests, plastic materials reduce the level of a plant's exposure to extreme weather conditions such as the extreme temperatures and sunlight in the tropics due to the unique photoselective properties that create a unique microclimate [5]. The material properties of the nets have improved over time, given advances in technology. Wang et al. reported the development of novel three-dimensional polymer nanofiber nets that are made using controllable fabrication techniques such as electrospinning/netting (ESN) [6], which enhances the Steiner tree network geometry, tensile 
strength, and porosity of the material. The elimination of plastic use on farms due to environmental sustainability considerations would involve a trade-off in terms of agricultural applications.

The new materials for plastic nets, environmental cost implications, and agricultural benefits underscore the importance of this study. The main question is whether the environmental considerations outweigh the agricultural benefits. This review builds upon published research relating to the production, use, and disposal of plastic nets in agricultural settings to provide a better understanding of the ecological costs and impact on sustainable agriculture, farming-related benefits, sustainable alternatives, and the effect of continued use of plastic nets on farms. A review was necessary, considering that there has been extensive research on the subject. Published research has investigated the mechanical properties of plastic nets [7], the types of polymer materials used in agricultural applications [1], the impact of plastic nets on the farm microclimate [3], the comparative effectiveness of different materials [5], emerging fabrication techniques [6], the mapping of agricultural waste using geo-informatics [8], geo-referencing [9], optical properties for optimal shading [10], and the development of biobased recycling materials and their impact on agricultural sustainability [11]. The diversity of these themes shows that an empirical study was not necessary. However, it was necessary to undertake a review to address the gaps in information relating to the sustainability of the plastic nets. Review publications relevant to the subject have only focused on the types of plastic nets available on the market and their applications [12]. There are also controversies surrounding the use of biobased plastic nets due to the lack of clear evidence concerning the sustainability of these materials vis-à-vis nonbiodegradable plastics. The mechanical properties of commonly used plastic nets are discussed in the next section.

\section{Material Properties of Plastic Nets}

\subsection{Material Quality Assessment}

Plastic nets and support structures vary in terms of the type of material and application. The methods used to assess spectral transmissivity, tensile strength, and plastic deformation are reviewed below.

\subsubsection{Spectral Transmissivity}

The material properties of plastic nets and support structures are assessed using radiometric tests [13]. The tests are conducted using a spectrophotometer whose wavebands are adjusted to measure spectral transmissivity. The main wavelength bands of interest are near-infrared, far-infrared, and photosynthetically active radiation (PAR), which have ranges of $290-2500 \mathrm{~nm}, 400-700 \mathrm{~nm}$, and above $2500 \mathrm{~nm}$. Additional measurements, such as spectral perpendicular transmissivity and are undertaken by UV-VIS-NIR spectrophotometer, and Fourier transform-infrared (FT-IR) spectrophotometer [4] (Figure 1). The specific procedures used to perform these measurements are reviewed by Castellano et al. [4] and Russo [14].

\subsubsection{Tensile Strength and Plastic Deformation}

Tensile tests are also critical in the assessment of the sustainability of plastics. In addition to spectral transmissivity, tensile tests are performed to predict the sustainability of plastic nets by determining their stress-strain behaviors, yield strength, brittleness, and fatigue limit using the ASTM standards [15]. The most common tensile tests are used in the assessment of a material's response to pulling force to determine the breaking point $[16,17]$. Materials that exhibit plastic deformation and necking are more appropriate for agricultural applications where severe meteorological hazards are common. Even though a higher tensile strength is desirable, the porosity of plastic nets coupled with the warp diameter requirements limit the tensile strength; this explains the unique stress-strain curves for the IMPOL specimen anti-insect nets [7] and SCMD specimen windbreak nets reported in Figures 2 and 3. 


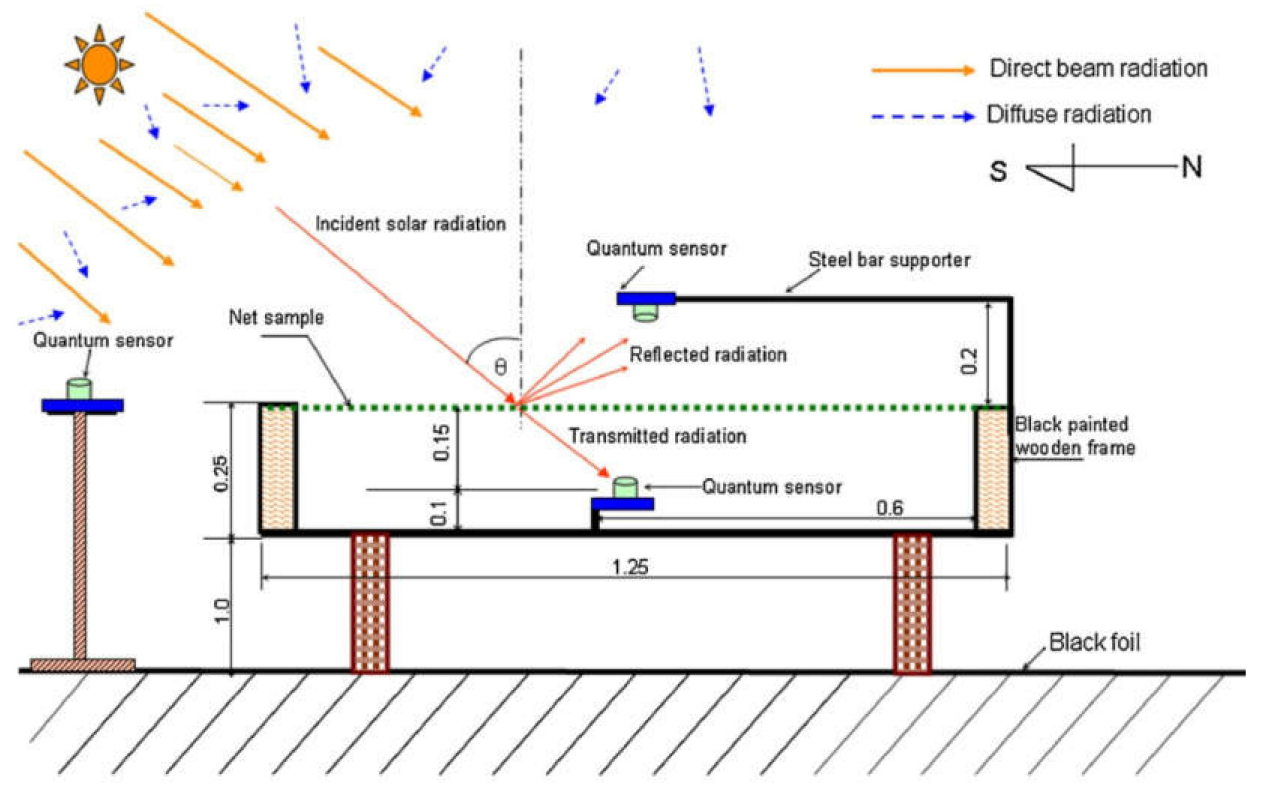

Figure 1. UV absorption and reflectance in controlled environments fitted with plastic shading nets (White-50, green-50, blue-80, and dark green-80) [13].

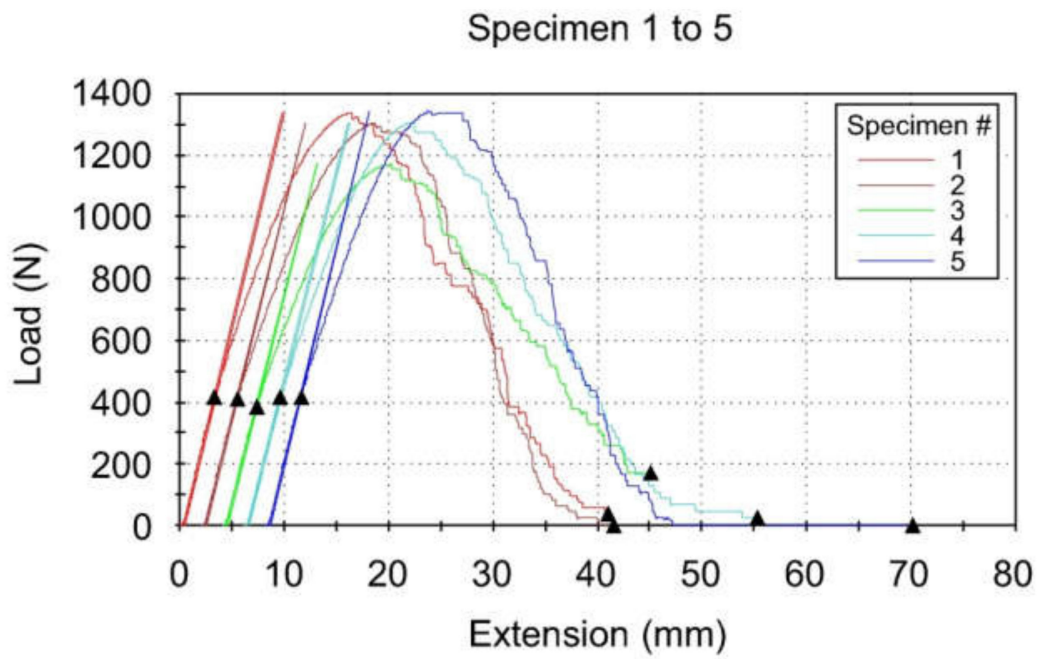

Figure 2. Stress-strain curves for SCMD specimen windbreak nets used in agricultural applications [7].

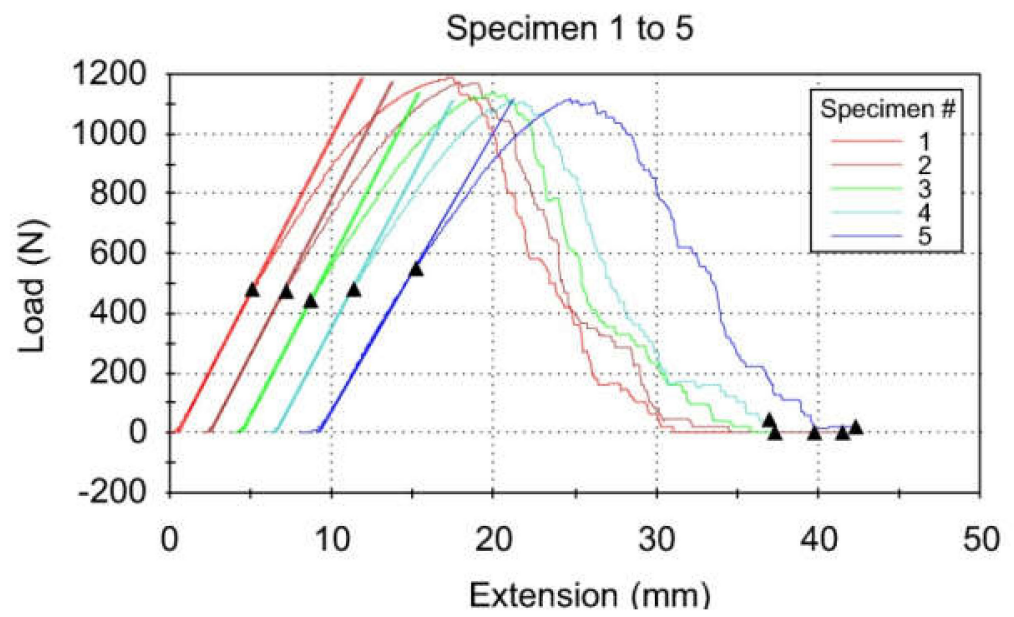

Figure 3. Stress-strain curves for IMPOL specimen anti-insect nets [7]. 


\subsubsection{The Impact of Weather on the Mechanical Properties of Nets}

The weather patterns influence the stress-strain behaviors (mechanical properties) and optical properties of plastic nets due to thermal instability. Polymer materials are deformed at high temperatures. The impact of temperature on plastic nets (HDPE-grade, PE-LD, EVAC plastic film, and PRISMA 90) was confirmed in Saudi Arabia and the Mediterranean region. The microstructural changes induced by sunlight and solar radiation were monitored using an ultraviolet-visible (UV) spectrometer in the near-infrared (NIR) region. The spectroradiometric tests confirmed that there was an overlap between the plastic nets and plastic films. The overlapping resulted in a greater shading effect, ranging between $34 \%$ and $70 \%$ [5]; it is of note that the reported shading effect was slightly lower compared to the plastic net in isolation (57\%). Even though the changes are small in terms of absolute values, they have a significant effect on plant growth. Statuto et al. reported a $2{ }^{\circ} \mathrm{C}$ increase in the soil and air temperature. Such an increase in temperature might be detrimental to the growth of temperature-sensitive plants [5]. The impact of temperature on the performance of plastic nets in protected cultivations was also confirmed by Al-Helal and Abdel-Ghany [13]. In particular, excessive UV radiation contributes to degradation. However, the impact of PAR can be addressed by customizing the porosity and color of the plastic nets-different colors have different reflectance values (refractive index and absorption coefficient) [13]. Plastic nets that selectively filter solar radiation are best suited for tropical and arid regions.

\subsection{Properties of Plastic Nets Used in Agricultural Applications}

The utility of plastic nets in agricultural settings is primarily influenced by the tensile strength, the yield strength, porosity, and Steiner tree network geometry, which influence the environmental suitability of the materials [6,18]. The material properties listed above are influenced by the quality of materials used in the manufacture of the plastic nets. According to Castellano et al. [4], the plastic nets used in protected cultivations are primarily made of polypropylene, starch-based biodegradable materials, polyethylene (PE), polyvinyl chloride, and high-density polyethylene (HDPE) [19]. The choice of one material in place of another is influenced by the application and sustainability considerations. For example, biodegradable plastic is highly desirable from a sustainability perspective because the material does not pollute the environment [20]. However, from a durability point of view, HDPE is suitable because it is impervious to water and other liquids, is not susceptible to UV radiation, and can be recycled [12]. HDPE has also been proven to have a high modulus of elasticity and elastic modulus, which approach the theoretical limits (70 GPa and $200 \mathrm{GPa}$, respectively) [21]. The mechanical properties are complemented by suitable electrical properties, including significant heat conductivity and sonic modulus, and limited dielectric loss. The ideal material properties, coupled with the low density, make the materials suitable for high-strength applications. However, the creep behavior of HDPE impacts the use of the material.

The protective effects against UV radiation are demonstrated in Figure 1. Briassoulis et al. noted that the mechanical properties of agricultural nets differ depending on the types used in farm environments [7]. The most common plastic nets for agricultural applications are shading nets, antihail, anti-insects, and windbreak. The unique properties associated with each type of net are discussed in the next section.

\subsubsection{Windbreak Plastic Nets and Anti-Insect Nets}

As the name suggests, windbreak nets are mainly used as windbreakers in farm environments to slow the movement of wind and its effect on plants. The nets are required to have high tensile strength and a linear elastic range in both directions to withstand wind pressure. Commercially available windbreak plastic nets exhibit greater tensile strength in the warp direction and plastic deformation at the breaking point both directions [7]. The strength of the plastic nets for windbreakers is reinforced by concrete, wood, or steel. The stress-strain curves are shown in Figure 2. The stress-strain curves are for 
the Seasonal Crop Moisture Deficiency (SCMD) type of plastic nets. The analysis shows that specimen five exhibited the best performance under optimal loads-an indication of the suitability of the net for agricultural applications. Even though the mechanical strength of the plastic windbreak nets is critical to farm-related applications, the support structures for the nets are also critical; for instance, ideal windbreaking is influenced by the height of the support structures and the relative distance from physical barriers such as fences to minimize the impact of shading [12], except in the cultivation of sweet peppers and other plants that are highly adapted to the shade [22]. Other critical parameters include the porosity of the plastic nets, which has to be tailored to limit the generation of wind vortices, which are harmful to fragile plants. The impact of net vortices can be regulated in the construction phase by selecting nets with appropriate net pressure coefficient ratios for the leeward and windward sides [23].

Higher tensile strength is not a prerequisite for anti-insect nets, but Briassoulis et al. noted that the nets have similar mechanical properties as windbreak nets, especially in terms of linear elasticity, elongation at the point of break, and brittleness [7]. Experimental evidence shows that the anti-insect nets have the same strength regardless of the direction. However, the elongation at break is higher. The tensile performance of the anti-insect net is illustrated in Figure 3.

Even though specimens of IMPOL and SCMD types of anti-insect and windbreak nets were primarily used in Briassoulis et al. for their mechanical properties, there are other suitable types of nets for these applications, as noted in Table 1. For example, the SC75 has a better elastic modulus compared to SCMD. In addition, INSK and INSM nets have a better elastic modulus in the insect category compared to IMPOL specimens. Plastic nets with better mechanical properties should be utilized where impact resistance is a key criterion. The anti-insect nets can help reduce farming expenses and the use of synthetic pesticides in the farming of plants such as lettuces, which are prone to pests [2]. Exclusion nets that limit the growth of the rosy apple aphid, codling moth, and Dysaphis plantaginea were piloted by Dib, Sauphanor, and Capowiez [24]. Their study confirmed that white nets helped to control the population of the codling moth, rosy apple aphid, and Dysaphis plantaginea (RAA), as shown in Figure 4. However, there was no conclusive evidence concerning the effectiveness of these nets in regulating the proliferation of other insects. Another concern is that the effectiveness of the anti-insect nets varied depending on the season and was inconsistent over time-based on a comparison of the trends reported for 2008 and 2009. The seasonal changes in the effectiveness of anti-insect nets raise fundamental concerns about the effectiveness of the plastic nets, considering they compromise the action of natural insect predators such as birds [25] and spiders [26] and the parasitoids of rosy apple aphids such as Hemiptera miridae and Neuroptera chyropsidae.

In the case of parasitoids, their foraging areas are impacted by the presence of exclusion nets because areas covered by the nets are inaccessible. The impact on foraging behaviors also extends to reproduction-there is limited space for laying eggs. Even though the impact of natural predators is compromised by the exclusion nets, Dib et al. [24] claimed that the population of the RAA was highly regulated in the apple plants that were covered by the exclusion nets compared to the uncovered plots. This seems to suggest that the impact of natural predators is nonsignificant, at least in apple plants. Despite the positive impact of the nets alone, the researchers acknowledged the importance of natural predators in integrated pest management. Further research is necessary to determine whether these observations are also applicable to other plants. The role of secondary predators such as F. auricularia and other earwig predators whose food cycle is based on the failure of primary methods of pest control should be explored. 
Table 1. Impact-related mechanical properties of different plastic nets [7].

\begin{tabular}{|c|c|c|c|c|}
\hline Shading Nets & $\begin{array}{c}\text { Mass of Dart } \\
\text { (g) }\end{array}$ & $\begin{array}{c}\text { Equivalent } \\
\text { Hailstone } \\
\text { Diameter }(\mathrm{mm})\end{array}$ & $\begin{array}{l}\text { Equivalent } \\
\text { Hailstone } \\
\text { Energy (J) }\end{array}$ & Comments \\
\hline OMBR50 & 444 & 52 & 39 & \\
\hline OMBR70 & X1568 & X75 & X166 & The samples do not break \\
\hline OMBR90 & X1568 & X75 & X166 & The samples do not break \\
\hline HEX & 1324 & 71 & 136 & \\
\hline LIBC30 & 717 & 60 & 68 & \\
\hline LIBC50 & X1568 & X75 & X166 & The samples do not break \\
\hline LIBC60 & X1568 & X75 & X166 & The samples do not break \\
\hline LIBC70 & X1568 & X75 & X166 & The samples do not break \\
\hline AGR30 & 418 & 51 & 37 & \\
\hline AGR50 & 510 & 48 & 29 & Method A \\
\hline AGREW & 452 & 47 & 25 & Method A \\
\hline SHNB & 852 & 63 & 82 & \\
\hline SHNT & & & & \\
\hline \multicolumn{5}{|l|}{ Antihail nets } \\
\hline FRU26 & 584 & 56 & 54 & \\
\hline FRU44 & 826 & 62 & 80 & \\
\hline IRID & 800 & 62 & 77 & \\
\hline ANTH & 634 & 58 & 59 & \\
\hline GRKR & 700 & 59 & 66 & \\
\hline \multicolumn{5}{|l|}{ Anti-insect nets } \\
\hline $\mathrm{BIO} 40$ & X1568 & X75 & X166 & Cracks along the circular grip \\
\hline BIO50 & X1568 & X75 & X166 & Cracks along the circular grip \\
\hline IMPOL & 593 & 57 & 54 & \\
\hline INSK & X1568 & X75 & X166 & Cracks along the circular grip \\
\hline INSM & X1568 & X75 & X166 & Cracks along the circular grip \\
\hline INST & X1568 & X75 & X166 & The samples do not break \\
\hline REMA & 356 & 49 & 30 & \\
\hline \multicolumn{5}{|l|}{ Windbreak nets } \\
\hline SC50 & X1568 & X75 & X166 & Cracks along the circular grip \\
\hline SC75 & X1568 & X75 & X166 & Cracks along the circular grip \\
\hline SCMD & X1568 & X75 & X166 & Cracks along the circular grip \\
\hline WINT & X1568 & X75 & X166 & Cracks along the circular grip \\
\hline BR 50 & $\mathrm{X} 1568$ & X75 & X166 & Cracks along the circular grip \\
\hline
\end{tabular}

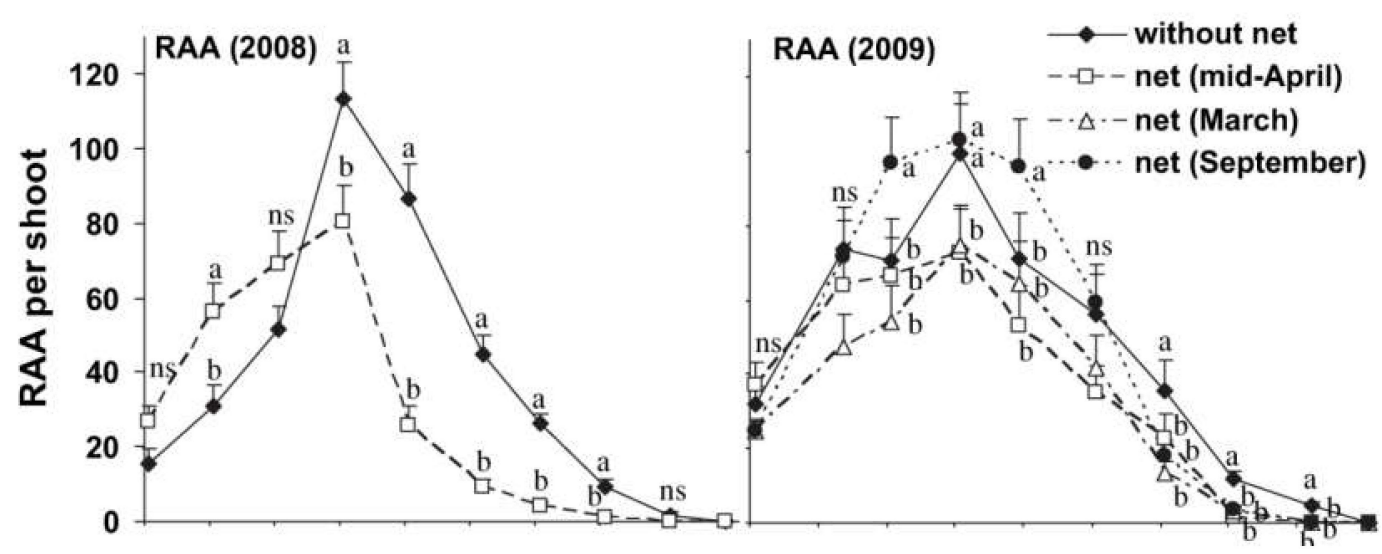

Figure 4. Impact of exclusion nets/anti-insect nets on the populations of the codling moth, rosy apple aphid (RAA), and Dysaphis plantaginea (DP) in apple orchards [24]. The label of the x-axis is time. The letters $a$ and $b$ denote the level of significance, while ns shows that there is a nonsignificant relationship. 
A reduction in pesticide application would contribute to sustainable farming, considering that synthetic pesticides are expensive [2] and potential food toxins in developing countries where post-harvest handling standards are disregarded. In brief, anti-insect plastic nets have the ability to enhance sustainability in the agricultural sector. Apart from pest management, plastic nets' contribution to agricultural sustainability also extends to farm yields and the availability of essential nutrients in the plants. Another use of plastic nets is for the construction of windows in greenhouses, where bumblebees are used for pollination [27].

The agricultural yields of plants can be enhanced by nets that transmit PAR in the range of 400-700 $\mathrm{nm}$ because higher radiation wavelengths are detrimental to plant growth. The specific range of PAR has been associated with specific photon flux ratios, and sunlight radiation influences stem cell elongation, which is a desirable property for horticultural crops. The impact of sunlight on yield has also been associated with changes in a plant's vegetation (which influences the absorption of essential nutrients) and the size of the fruits [28]. In another experiment, it was confirmed that biobased plastics with anti-insect properties had an impact on the shelf life of cultivated plants, especially tomatoes. The extension of the shelf life can be explained by the mitigation of pest attacks, which cause blossom-end rot and other physiological disorders [29]. The impact of UV and PAR on plant health and yield shows that it is necessary to install nets that are capable of absorbing the appropriate quantities of PAR.

A comparative analysis of the different types of nets by Legarrea et al. established the following. One, there were inconsistencies in the UV radiation transmittance depending on the material properties of the nets. Anti-insect nets made of polyethylene had the highest levels of UV light transmittance at $75 \%$ [28]. In contrast, BioNet (colored white) had the lowest UV transmittance at $<40 \%$. Considering that the two types of nets (anti-insect nets and BioNet) were made of similar materials, the variations in UV radiation transmittance could be linked to the color of the plastic nets-the BioNets were colored white. The relationship between plastic net color and the amount of solar radiation that reaches the plant canopy is presented in Figure 5. A contrary phenomenon was observed in dark green plastic nets [10]. Apart from the surface color, the PAR transmission and reflection of solar radiation have been regulated by the photoselective netting concept [11]. The impact of photoselectivity on yield is reported in Section 2.4.1. Further information on the radiometric performance of the agricultural nets is found in $[14,30,31]$.

Table 2. Impact of plastic net microclimate on the availability of anti-oxidants in plants [25] (DW denotes dry weight).

\begin{tabular}{ccccccc}
\hline Cultivar & Environment & $\begin{array}{c}\text { Capsanthin } \\
\text { (mg Lutein } \\
\text { Eq./100 g DW) }\end{array}$ & $\begin{array}{c}\text { Lutein } \\
(\mathbf{m g} / \mathbf{1 0 0} \text { g } \\
\text { DW) }\end{array}$ & $\begin{array}{c}\boldsymbol{\beta} \text {-Cryptoxanthin } \\
\text { (mg/100 g DW) }\end{array}$ & $\begin{array}{c}\boldsymbol{\beta} \text {-Carotene } \\
\text { (mg/100 } \\
\text { DW) }\end{array}$ & $\begin{array}{c}\text { Phytoene } \\
\text { (mg/100 g } \\
\text { DW) }\end{array}$ \\
\hline Cultivator \#1 & Shade net & 69.01 & 6.93 & 1.19 & 4.36 & $0.45 \mathrm{~h}$ \\
& Tunnel & 83.76 & 11.79 & 1.47 & 8.70 & 0.79 \\
Cultivator \#2 & Shade net & 69.81 & 9.57 & 1.33 & 6.22 & 0.59 \\
& Tunnel & 72.57 & 13.53 & 1.36 & 10.19 & 0.753 \\
Cultivator \#3 & Shade net & 109.89 & 11.92 & 1.67 & 8.46 & 0.91 \\
& Tunnel & 108.98 & 19.66 & 1.99 & 19.76 & 1.62 \\
Cultivator \#4 & Shade net & 80.25 & 7.20 & 1.34 & 4.85 & 0.64 \\
& Tunnel & 76.31 & 17.63 & 1.60 & 11.93 & 0.90 \\
& Shade net & 56.77 & 6.00 & 1.33 & 5.28 & 0.61 \\
& Tunnel & 61.264 & 12.22 & 1.50 & 12.44 & 1.139 \\
\hline
\end{tabular}




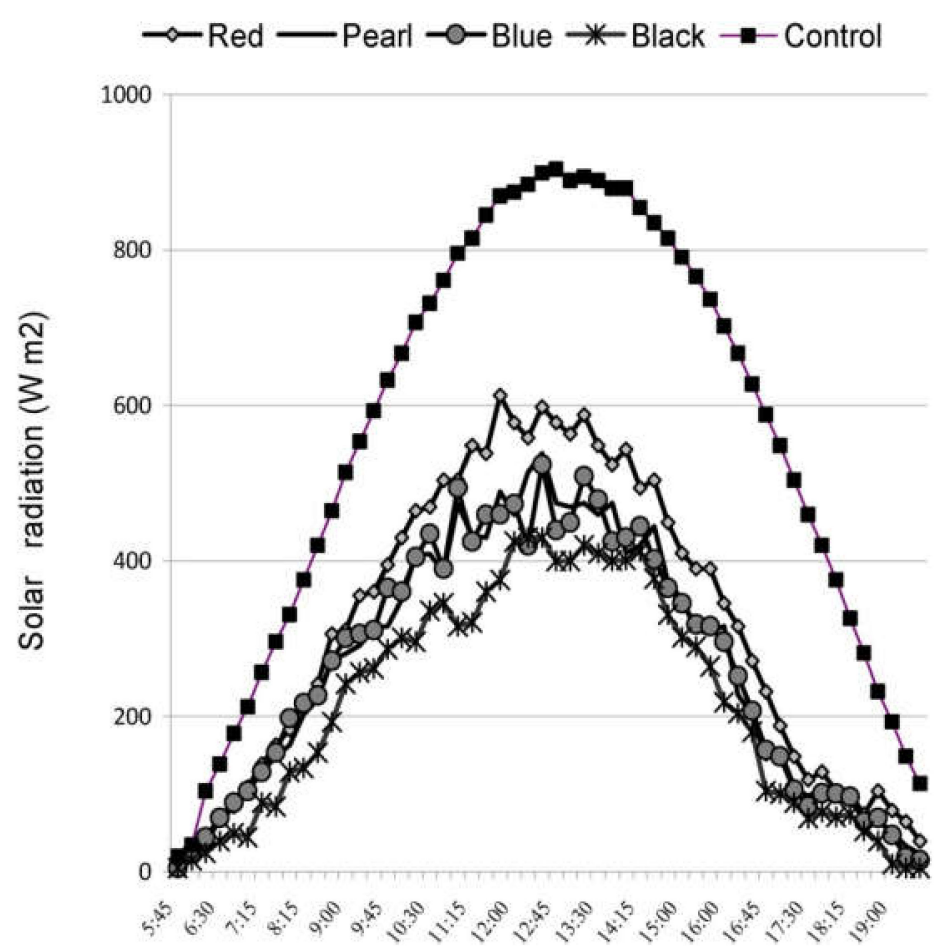

Figure 5. Relationship between the shade plastic net color (with an index of 50 and above) and the solar radiation that reaches the plant canopy $\left(\mathrm{W} / \mathrm{m}^{2}\right)$ [32].

Lekala et al. noted that the presence of essential nutrients such as $\beta$-carotene and antioxidants such as polyphenols and carotenoids was substantially higher in plants grown in tunnels compared to the shade nets, as noted in Table 2 [33]. However, the observations were not consistent: cultivator \#1 reported higher concentrations of capsanthin, $\beta$-cryptoxanthin, and $\beta$-carotene in plants grown in tunnels rather than shade nets. Even though the changes were inconsistent in the five cultivator datasets, there was a causal relationship between the applications of shade nets and fluctuations in the levels of essential anti-oxidants. The changes could be due to the daytime and nighttime temperatures, the transmission of photosynthetic active radiation (PAR), and exposure to infrared radiation. The level of total PAR was slightly higher in the shade nets (671 versus $461 \mathrm{~nm}$, respectively) [33].

The use of plastic nets did not impact market yields-plants grown in the open field/tunnels had the same market yield as plants covered in plastic nets. The nonsignificant impact of plastic nets on plant yield was also reported in the investigation of the effectiveness of biobased plastic nets used in the cultivation of tomatoes [29]. However, the current data are inadequate to determine whether there was a causal relationship between the use of plastic nets and limited improvements in yield. Given the lack of sufficient data for other plants, the findings might only be applicable to sweet peppers and tomatoes, which were the main plants under investigation.

Boini et al. reported that the type of shading material used on the farm influenced sap and fruit growth. The observation is explained by the variations in the photoselectivity of plastic nets; changes in photoselectivity predict stomatal conductance, leaf gas exchanges, light and vapor pressure, and incident radiation; these properties affect physiological and photomorphogenic characteristics and other processes [34]. The study also confirmed that the color of the plastic net influenced the photoselectivity of the nets: blue light had a positive effect on leaf development, while the absolute growth rate of the plants was impacted by red color [34]. The impact of color on the spectral transmissivity and optical properties of the plastic nets was also confirmed by Abdel-Ghany and Al-Helal [35], whose study indicated that the solar energy transmitted from the net pores $\left(E_{S C}\right)$ was higher in white, orange, and beige nets. In contrast, $\mathrm{E}_{\mathrm{SC}}$ was lower in green nets, as shown in Figure 6. Optimal $\mathrm{E}_{\mathrm{SC}}$ was reported between 10 and $14 \mathrm{~h}$. The two studies show that there was a significant relationship between 
the optical properties of nets and color. However, the impact of color varies in line with changes in the incident angles and texture of the net (knitted wires, irregular mesh; interlaced wires; parallel strips) [36]. The reproducibility and reliability of the photoselective experiments were not determined because no similar study has been undertaken using apple plants. Other research experiments also noted that the relative shading [37] was complementary to the surface color, given the impact on light intensity. Further data on spectroradiometrical characterization, radiometric performance, and color are published in the [38-40].
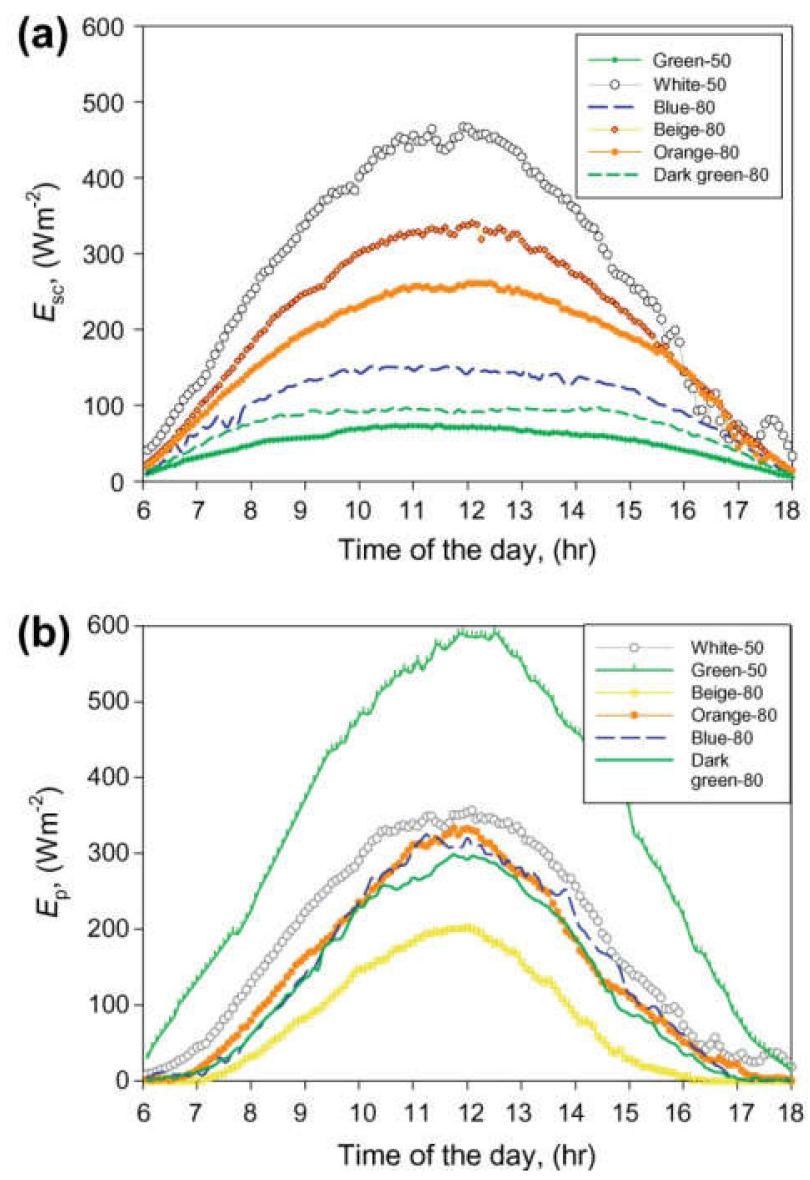

Figure 6. Impact of plastic net color on the solar energy transmitted from the net pores: (a) forward scattering of incident radiation; (b) unscattered radiation emanating from the net pores [29]. The plastic nets used in the experiment had opaque threads and differences in net porosity.

\subsubsection{Antihail Plastic Nets and Shading Nets}

Similar to anti-insect nets and windbreak nets, antihail nets are required to manifest appropriate mechanical properties, including plastic deformation and elongation. However, for plastic nets to withstand the impact pressure of hail, they are required to exhibit both linear and nonlinear elastic and linear elastic behavior in the weft and warp directions, respectively [7]. The optical properties of plastic nets are essential criteria for nets used in shading applications. The stress-strain curves for antihail and shading nets are shown in Figures 7 and 8. One of the standard features in the curves is significant lateral contraction and brittleness. Therefore, the production of these nets should be customized to match the farm applications and the weather patterns-farms at risk of hailstorms should be fitted with nets with higher impact strengths. 

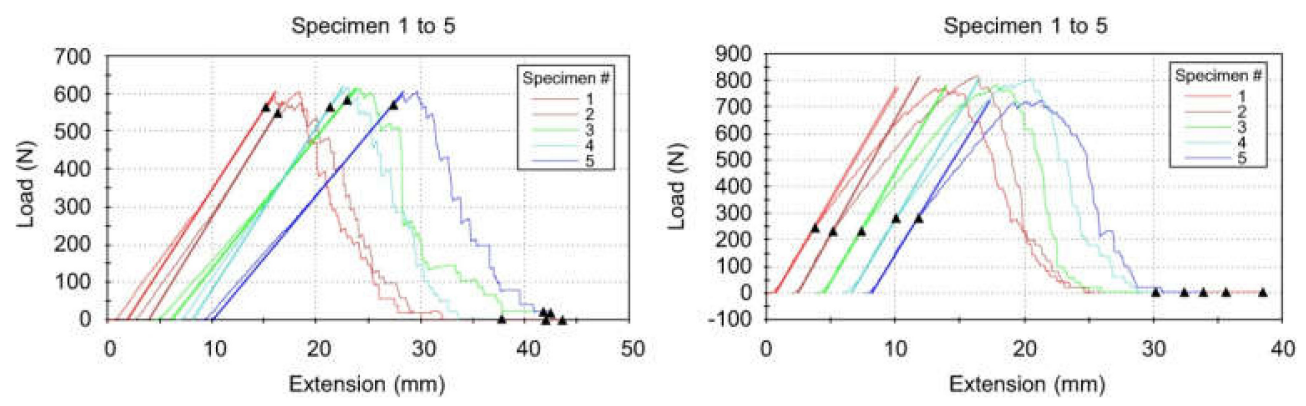

Figure 7. Stress-strain curves for antihail agricultural plastic nets (plastic type: FRU44) [7].
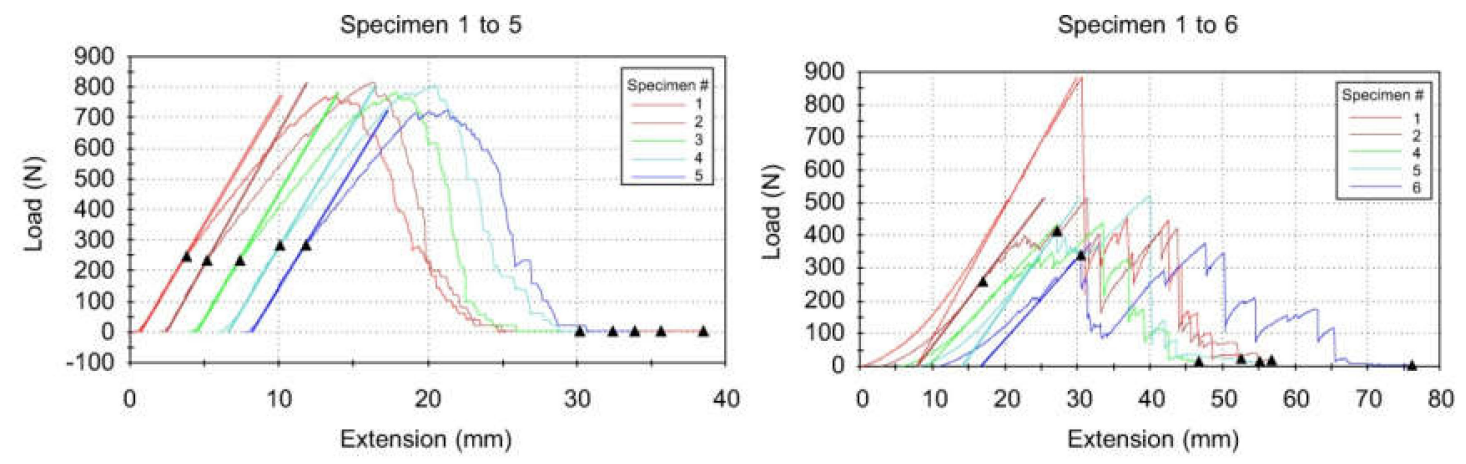

Figure 8. Stress-strain curves for agricultural shading nets used in farms (plastic type: OMBR70) [7].

The mechanical and optical properties of the four main types of plastic nets show that anti-insect nets are least suitable even though they serve a dual purpose- they reduce pests and disease and contribute to the creation of a microclimate that facilitates the growth of plants. The limited suitability of plastic nets is based on the alteration of a plant's microclimate. Yang et al. reported that anti-insect nets modified the radiation regime and reduced the airspeed, which in turn affected plant growth and physiology [3]. A decline in airspeed elevates airflow resistance and suppresses the flow of $\mathrm{CO}_{2}$, which is critical for photosynthesis [3]. In addition, reduced airflow increases humidity and temperature, which is detrimental for plants that grow best in a controlled environment. Despite the limitations, anti-insect nets are necessary for IPM. The influence of the weather patterns, especially meteorological hazards (hail, wind, snow, storms, and excess sunlight), on the economic and technical sustainability of plastic nets is discussed in the next section.

\subsection{Modification of the Mechanical and Optical Properties of Nets}

The environmental sustainability of plastic nets for agricultural applications can be enhanced by modifying the surfaces of the nets to facilitate cross-application (such as the use of antihail nets in pest control). Alternatively, the sustainability of the nets can be enhanced by increasing the biodegradability. The surface modification of plastic nets is discussed in the next section.

\subsubsection{Surface Modification of Plastic Nets}

The surface modification of plastic nets enhances the mechanical properties and the range of applications. There are different forms of surface modifications including painting (coloring the nets white, red, light and dark blue, and yellow to regulate the absorption of PAR and UV light) [13,41] and coating with pesticides as part of integrated pest management (IPM) [41]. Pyrethrum-treated plastic nets were found to be effective against insect vectors and viruses in the cultivation of vegetables. The main question is whether the application of pesticides to the nets reduced the need for customized ant-insect plastic nets given the risk of resistance to pesticides. In addition, the current research does not indicate whether pyrethrum was effective against other pests and viruses apart from Bemisia tabaci 
(Gennadius), Cucumber mosaic virus (CMV, Cucumovirus), Myzus persicae Sulzer, Aphis gossypii Glover, Cucumber aphid-borne yellows virus, and Polerovirus.

Other treatment methods have been developed, including coating with silver nanoparticles. Simone et al. confirmed the effectiveness of silver in preventing the growth of bacteria on HDPE plastic nets [20]. E. coli were effectively treated using silver-coated HDPE nets, and it is also possible that the treatment would be effective in the management of mild bacterial strains. From an economic sustainability perspective, the utilization of plastic nets treated with silver could contribute to the environmental sustainability of plastic nets for the following reasons. First, the extensive use of pesticides for surface modification is sustainable based on cost considerations, the impact on human health, and the emergence of pesticide-resistant pests. Second, there is a growing demand for integrated pest management that integrates pest management and protection from meteorological hazards such as hail and excess UV radiation [12,41]. The only impediment is the duration of the effectiveness of the treatment in field conditions. Current trials suggest that surface treatment is effective for three years or more [41,42]. The economic and technical sustainability of biobased plastics is discussed in the next section.

\subsubsection{Microstructure Modification through Electrospinning}

Surface modification techniques are limited due to the limited modification of the microstructure-a problem that has been addressed through advanced nanotechnology methods such as electrospinning [6]. The technique involves the modification of the properties of the material (composition, surface area, and porosity) through electrohydrodynamics and phase separation using a high-pressure liquid jet. A reduction in the size of the pores impacts the surface area because there is a proportional relationship between the pore sizes and surface area. Current progress in research has facilitated the development of plastic nets with controllable composition, customized porosity, and surface area, as illustrated in Figure 9 . The shape of the pore and microstructure exhibits a Steiner minimal tree network, which is bio-inspired and commonly observed in biological organisms such as honeycomb, sisal, and spiderwebs. In general, the interlinking of the one-dimensional electrospun fibers impacts agricultural application-material characterization data suggest that the plastics have high mechanical strength based on the extent of the cross-linking. The product derived from the electrospinning process varies depending on the precursor and the solvents.
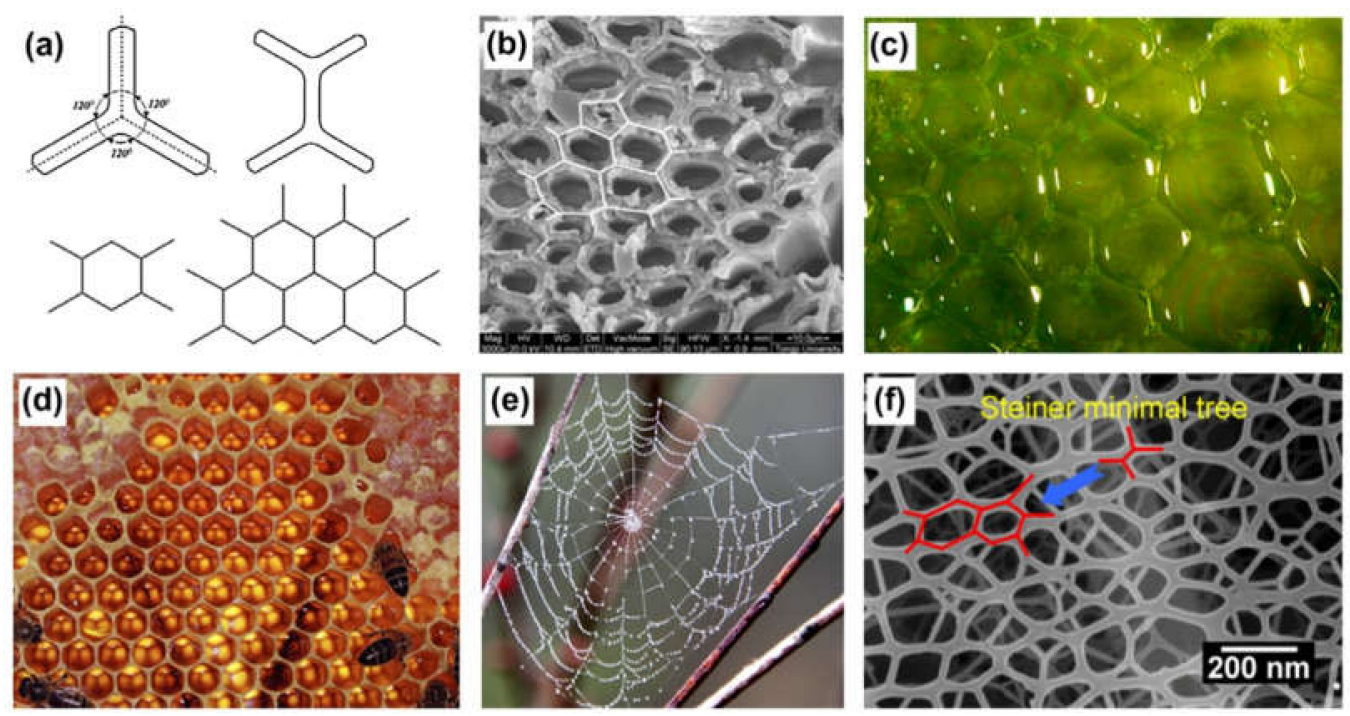

Figure 9. Pores and microstructure of electrospun plastics and their inspirations: (a) nanochannel template; (b) sisal cell wall; (c) soap bubbles; (d) honeycomb structure; (e) cobweb; (f) nanonet structure exhibiting Steiner minimal tree configuration [6]. 


\subsection{Biobased Plastic Nets}

As noted in the preceding sections, biobased polymers have been extensively explored as an alternative to polymer-based nets $[43,44]$. Scholarly and industrial interest in biobased and sustainable farming nets is validated by concerns about the environmental effects and the need to safeguard crop health through sustainable interventions [20]. The biobased plastics are grouped into two subgroups, natural and synthetic. Synthetic biobased polymers contain polysaccharide derivatives (DS), polyhydroxybutyrate (PHB), polycaprolactone (PCL), and polylactic acid (PLA) [43,44]. In contrast, natural biobased polymers comprise polyhydroxylalkanoate (PHA), polyamino acids, cellulose/starch, and proteins [45]. The impact of the raw/source materials on the biodegradation of biobased plastics is illustrated in Figure 10.

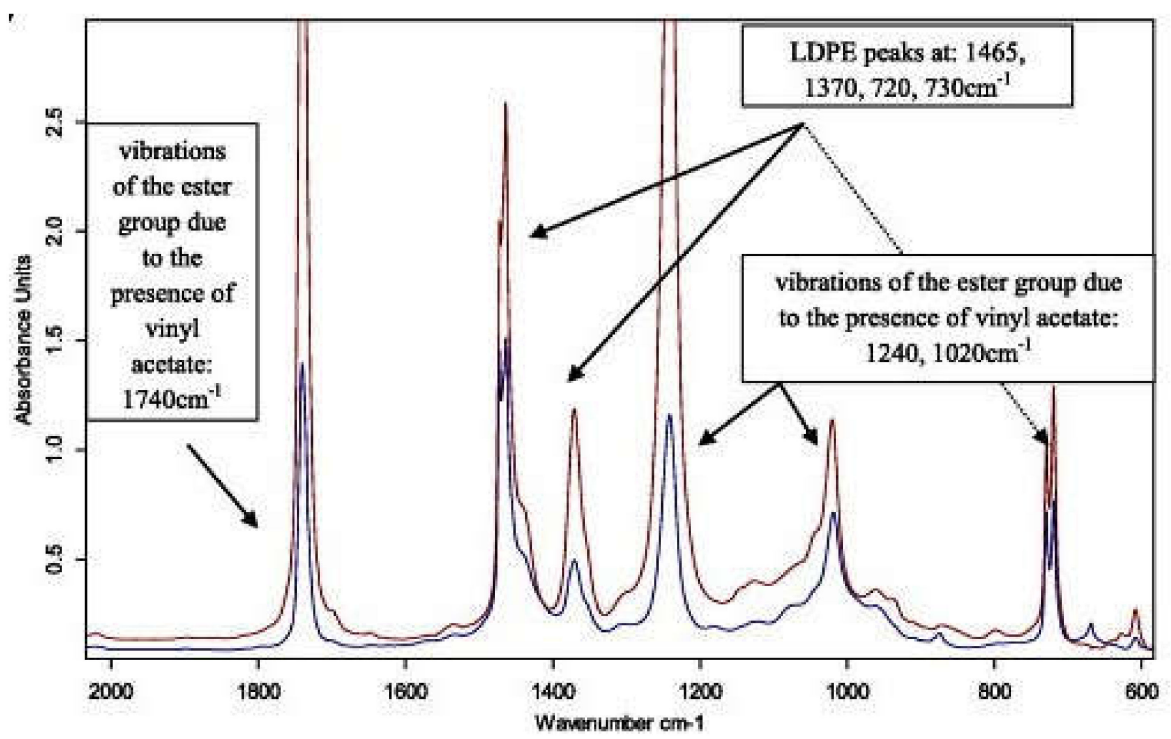

Figure 10. MidIR transmission spectra of polymers for plastic nets [35].

The composition of the biobased plastics can also be modified to match the applications: the mitigation of tomato pest attacks was achieved by biobased plastic nets made from cinnamon bark essential oil (CEO), poly(butylene adipate-co-terephthalate) (PBAT), and polylactic acid, as noted by Black-Solis et al. [29]. The biobased plastic nets are primarily sourced from plant sources, including starch or agricultural feedstock. Lorcks [46] claims that scientists have developed facile and scalable methods for producing commercially viable quantities of starch-based bioplastics, including thermoplastic starch (TPS). Plastics that are derived from TPS such as BIO FLEX have exhibited comparable properties to standard plastics, except in terms of biodegradation and eco-friendliness [46]. The properties include opaqueness, transparency, surface color modification, permeability to vapor, impermeability to oxygen, and shrinking ability. The main method that is employed in the production of these materials is a reaction compounding the extrusion and optimization of the compostable raw materials [46]. However, the new methods have not resulted in a significant improvement in the commercial production of bioplastics, as noted by Hatti-Kaul et al. [11]. The global production capacity of biobased plastics is not comparable to that of polymer-based plastics, which are sourced from oil-based fossil fuel sources. As of 2016, the production capacity of biobased plastics was less than 1\% of the total plastics produced; this is despite an annual growth rate of about $20 \%-30 \%$ and widespread awareness of issues of environmental sustainability.

Beyond commercial production, there are concerns about the variability in the rates of biodegradation. Even though the plastics are sourced from agricultural feedstock such as wheat and corn [19], they have different levels of biodegradability, in line with their stereochemistry, length of side chains, and susceptibility to hydrolysis. PHB is highly biodegradable compared to PCL or PLA. Based 
on the limited biodegradability, the application of biobased plastic nets involves a tradeoff between material properties and technical sustainability.

Biobased plastics do not possess the standard mechanical properties for agricultural applications-this shortcoming is addressed by blending with nonbiodegradable plastics. The blending process has mixed benefits. On the one hand, it diminishes the recyclability of these materials [44]. On the other hand, it significantly enhances the material properties. Other concerns include the fact that facile synthetic routes have not gained global recognition because genetic engineering of microorganisms is opposed by a section of the scientific community [44]. Researchers have not been able to develop an effective biodegradation trigger, which is crucial to the technical and economic sustainability of plastic nets. The inability to develop an effective biodegradation trigger has been associated with the diverse applications of biobased plastics. The plastics are used in other applications apart from protecting plants from pests and meteorological hazards; these applications require customization of the mechanical properties, which are influenced by the lamellar thickness, molecular conformation, and crystallinity [44].

Mukherjee et al. noted that biobased polymers have a limited lifespan —on average, the polymers are functional for a period of 4-6 years, after which they are ready for disposal [19]. The short life cycle remains an issue considering that there are no established protocols for recycling biobased plastics and the existing ASTM D5033 regulations for the recycling of plastic waste do not apply. In general, the commercial viability of biobased plastic nets has been impeded by the lack of a scalable synthetic route and technological limitations in industrial biotechnology. Even if the base polymer is degradable, other substances used to give the material certain characteristics are added, such as nickel quencher, indurent gel, and anti-UV coating. These substances are of chemical origin and are often harmful to human health and the environment. The heart of the matter is that there is no "green chemistry" that is capable of providing additives for degradable plastics that are also degradable. Research must develop in this area.

Despite the production-related challenges, Hatti-Kaul et al. reported commendable progress in the synthesis of biobased plastics, as noted in Table 3 [11]. The data presented in Table 3 show that existing companies such as Luminy, Aircarbon, and Total have the capacity to produce large quantities of biobased plastics. The impact of the technical constraints is amplified by the absence of a suitable legal framework and technical specifications in the EU [47,48]. Current regulations (such as the Waste Framework Directive 2008/98/EC; Landfill Directive 99/31/EC; Revised Waste Framework Directive 2008/98/EC) relating to agricultural plastic waste do not cover biobased plastic materials [47]. In the absence of a suitable legal framework, the disposal of biobased plastics is a challenge. New regulations should be developed considering that biobased plastics are not entirely biodegradable-they contain polymer additives, heavy metals, and volatile compounds, which are included to enhance the mechanical properties of the materials. The primary concern is the lack of green chemistry methods.

Table 3. Commercial production of biobased plastics [10].

\begin{tabular}{|c|c|c|c|}
\hline Polymer & $\begin{array}{l}\text { Annual } \\
\text { Production } \\
\text { (Tons) }\end{array}$ & $\begin{array}{l}\text { Examples of } \\
\text { Trademark/ } \\
\text { Company }\end{array}$ & Application \\
\hline PLA & 217,000 & $\begin{array}{c}\text { Ingeo/NatureWorks; } \\
\text { Luminy/Total } \\
\text { Corbion; Lacty/ } \\
\text { Shimadzu Cor.; } \\
\text { Vyloecol/Toyobo }\end{array}$ & $\begin{array}{c}\text { Packaging materials, } \\
\text { medical implants, 3D } \\
\text { printing polymers, } \\
\text { textiles, electronics }\end{array}$ \\
\hline PHA & 30,000 & $\begin{array}{c}\text { Minerv-PHA TM/Bio- } \\
\text { On; PHBH TM/Kaneka; } \\
\text { TephaFlex/Tepha; } \\
\text { Nodax TM/Danimer } \\
\text { Scientific; AirCarbon/ } \\
\text { Newlight Technologies }\end{array}$ & $\begin{array}{c}\text { Packaging, compost } \\
\text { bags, tissue } \\
\text { Engineering }\end{array}$ \\
\hline
\end{tabular}


Based on these statistics, it will take time for fossil-fuel-based plastics to be phased out in agriculture and replaced with biobased plastics; without $100 \%$ recyclable and degradable plastics, environmental sustainability concerns would continue to abound in commercial agriculture. In general, the issue of sustainability should be considered from other dimensions beyond the degradation of plastic nets. Researchers can focus on the lifecycle costs of plastic nets and recycling to generate other useful materials.

\subsubsection{Impact of Biobased Plastics on the Quality Ratios}

Experimental evidence has confirmed that different types of plastics have a distinct effect on the quality ratios in plants, namely fruit yield, firmness, weight loss, total soluble solids, color, carotenoids, and titratable capacity [29]. Each of the biomaterials incorporated into the biobased plastics had a distinct impact on pest management; optimal management of the Alternaria alternate was reported in biobased plastic fibers that were made of 6\% CEO [29]. The impact of CEO content on the quality ratios of tomatoes pre- and post-harvest is presented in Table 4 . The use of biobased plastic contributed to the buildup of ethylene and anti-oxidants, which inhibited the in vitro growth of pests. In general, the effectiveness of CEO against pests is based on the anti-oxidant capacity. The antipest properties are time-dependent: an increase in time translates to a decline in the inhibitory effects. The loss of pest inhibition capacity can be resolved through surface modification, especially with the application of chitosan (a naturally occurring fungicide extracted from the exoskeleton of lobsters, shrimps, crabs, and shellfish). On the downside, the rate of biodegradation of the CEO was lower compared to PLA after 24 weeks. If PLA and CEO are integrated into biobased plastics, there is a tradeoff between environmental sustainability and pest management. New biobased plastic net materials are required to possess high antipest capabilities and natural degradation in the environment; this can be achieved through surface doping, the reduction of nonbiodegradable, additives and photodegradation. The impact of additives is illustrated in Figure 11; cellulose-based polymer materials achieved an optimal photodegradation rate of $70 \%$ after 350 days-the biodegradation curve shows that natural biobased plastics are not $100 \%$ effective.

The impact on the quality ratios is not unique to biobased plastic nets. Ilic et al. reported higher tomato fruit yield in plots that were fitted with photo-selective nets with $40 \%-50 \%$ shading [37]. The light intensity attributed to different shading also had an impact on the morphological properties of lettuce, and the duration from germination to maturity [32]. In particular, differences in the color schemes resulted in significant changes in head diameter, plant head weight, the intensity of the green color on the leaves, the length of the leaves, and the time between planting and bolting. In addition to the visual properties, the nutritional content of the lettuce was also affected by plastic net shading. In general, the chlorophyll, phenol, and flavonoid content was higher in plants cultivated under plastic nets compared to those in the open field. The suitability of $40 \%$ shading was also confirmed in the cultivation of sweet peppers in Serbia [22]. An improvement in the chlorophyll and carotenoid content and fruit pericarp thickness was also reported for sweet pepper plants grown under plastic nets. However, the content of total soluble solids was lower [22]. The findings underscore the superiority of plastic nets for enhancing agricultural yields and quality ratios. Apart from the regulation of PAR transmittance, light intensity, and heat in a greenhouse, the color of the plastic nets predicted the risk of pest/fungal attack and the prevalence of physiological disorders. The data in Table 5 show the risk of sun cracking, sun scalding, and blossom end rot. The variations in pest attacks are linked to the transmission coefficients presented in Table 6. 
Table 4. Impact of cinnamon bark essential oil on the quality ratios of tomatoes pre- and post-harvest [36].

\begin{tabular}{|c|c|c|c|}
\hline \multirow{2}{*}{$\begin{array}{c}\text { Treatments } \\
\text { Control }\end{array}$} & $\begin{array}{c}\text { At Harvest } \\
\text { Weight Loss } \pm \text { SD (\%) }\end{array}$ & \multicolumn{2}{|c|}{ After Eight Days of Storage } \\
\hline & - & 4.0 & $\pm 1.3 \mathrm{a}$ \\
\hline Nets without CEO & - & 4.2 & $\pm 1.2 \mathrm{a}$ \\
\hline Nets with CEO & - & 4.2 & $\pm 2.0 \mathrm{a}$ \\
\hline Control & Firmness $\pm \mathrm{SD}(\mathrm{N})$ & 20.3 & \pm 13.9 a B \\
\hline Nets without CEO & $\pm 7.3 \mathrm{~b} \mathrm{~A}$ & 26.2 & \pm 12.1 a B \\
\hline Nets with CEO & \pm 15.4 a $\mathrm{A}$ & 27.9 & \pm 11.8 a B \\
\hline Control & $\begin{array}{c}\text { Total soluble solids } \pm \\
\text { SD (\%) } \\
5.2 \pm 0.5 \text { a A }\end{array}$ & 5.2 & $\pm 0.8 \mathrm{~b} \mathrm{~A}$ \\
\hline Nets without CEO & $5.3 \pm 0.7$ a A & 5.0 & \pm 1.1 a $\mathrm{A}$ \\
\hline Nets with CEO & $5.5 \pm 0.9$ a A & 6.1 & $\pm 1.3 \mathrm{~b} \mathrm{~A}$ \\
\hline Control & $\begin{array}{c}\text { Titratable acidity } \pm \text { SD } \\
0.27 \stackrel{(\%)}{0} \underset{ }{0.04} \text { a A }\end{array}$ & 0.29 & \pm 0.06 a A \\
\hline $\begin{array}{l}\text { Nets without CEO } \\
\text { Nets with CEO }\end{array}$ & $\begin{array}{l} \pm 0.08 \text { a A } \\
\pm 0.05 \text { a A }\end{array}$ & $\begin{array}{l}0.32 \\
0.35\end{array}$ & $\begin{array}{l} \pm 0.09 \text { a A } \\
\pm 0.08 \text { a A }\end{array}$ \\
\hline Control & Color $($ Hue $) \pm S D$ & 91.8 & \pm 5.3 a B \\
\hline Nets without CEO & $\pm 4.2 \mathrm{a} A$ & 94.8 & \pm 1.8 a $\mathrm{A}$ \\
\hline Nets with CEO & \pm 3.6 a A & 95.6 & \pm 3.4 a B \\
\hline Control & $\begin{array}{c}\text { Total carotenoids } \pm \text { SD } \\
\left(\mu \mathrm{g} \mathrm{g}^{-1}\right) \\
6.7 \pm 1.5 \mathrm{~b} \mathrm{~A}\end{array}$ & 40.0 & $\pm 5.5 \mathrm{~b} \mathrm{~B}$ \\
\hline Nets without CEO & $4.1 \pm 1.9$ a A & 31.2 & \pm 8.9 a B \\
\hline Nets with CEO & $4.9 \pm 1.8$ a A & 36.5 & \pm 9.9 a b B \\
\hline Control & $\begin{array}{l}\text { DPPH reduction } \pm \text { SD } \\
(\%)\end{array}$ & 36.8 & \pm 6.6 a B \\
\hline Nets without CEO & $\begin{array}{c} \pm 6.4 \text { a A } \\
\pm 10.4 \text { с A }\end{array}$ & 41.3 & $\pm 8.2 \mathrm{~b} \mathrm{~B}$ \\
\hline Nets with CEO & $\pm 6.4 \mathrm{~b} \mathrm{~A}$ & 48.8 & \pm 9.9 с B \\
\hline \multirow{2}{*}{ Control } & $\mathrm{CO}_{2}$ production & $\mathrm{SD}(\mathrm{mg} \times$ & $\left.h^{-1}\right)$ \\
\hline & \pm 10.5 a $\mathrm{A}$ & 40.3 & \pm 19.7 a B \\
\hline Nets without CEO & $\pm 12.8 \mathrm{~b} \mathrm{~A}$ & 33.5 & \pm 17.6 a B \\
\hline Nets with CEO & $\pm 17.2 \mathrm{~b} \mathrm{~A}$ & 46.2 & \pm 19.2 a A \\
\hline & Ethylene productic & $\pm \mathrm{SD}(\mu \mathrm{g}$ & $\left.\times \mathrm{h}^{-1}\right)$ \\
\hline itrol & $1.0 \pm 1.1 \mathrm{a} \mathrm{A}$ & 2.0 & $\pm 1.4 \mathrm{a} \mathrm{B}$ \\
\hline Nets without CEO & $1.8 \pm 1.1 \mathrm{a} \mathrm{A}$ & 0.7 & \pm 0.5 a B \\
\hline Nets with CEO & $9.0 \pm 9.7 \mathrm{~b} \mathrm{~A}$ & 6.3 & $\pm 9.0 \mathrm{~b} \mathrm{~A}$ \\
\hline
\end{tabular}

Table 5. Link between net color and physiological disorders in tomatoes and yield [42].

\begin{tabular}{|c|c|c|c|c|c|c|c|}
\hline $\begin{array}{c}\text { Treatment } \\
\text { (Shade Nets) }\end{array}$ & Color & $\begin{array}{l}\text { Shading } \\
\text { Intensity }\end{array}$ & $\begin{array}{l}\text { Blossom } \\
\text { End Rot }\end{array}$ & "Cat Face" & Sun-Scald & $\begin{array}{c}\text { Skin } \\
\text { Cracking }\end{array}$ & $\begin{array}{l}\text { Marketable } \\
\text { Fruit Yield }\end{array}$ \\
\hline Control & No shading & None & $2.2 \mathrm{a}$ & $6.7 \mathrm{a}$ & $11.6 \mathrm{a}$ & $15.6 \mathrm{a}$ & $63.9 \mathrm{~b}$ \\
\hline Gr 34 & Green strips & $34 \%$ & $1.6 \mathrm{a}$ & $4.3 \mathrm{a}$ & $0.0 \mathrm{~b}$ & $8.2 \mathrm{~b}$ & $86.0 \mathrm{a}$ \\
\hline B and Gr 40 & $\begin{array}{l}\text { Black and } \\
\text { green strips }\end{array}$ & $40 \%$ & $1.4 \mathrm{a}$ & $5.2 \mathrm{a}$ & $1.0 \mathrm{~b}$ & $6.9 \mathrm{~b}$ & 85.6 a \\
\hline B 40 & Black strips & $40 \%$ & $1.4 \mathrm{a}$ & $1.7 \mathrm{a}$ & $0.0 \mathrm{~b}$ & $8.0 \mathrm{~b}$ & $88.3 \mathrm{a}$ \\
\hline B 49 & Black strips & $49 \%$ & $0.8 \mathrm{a}$ & $3.8 \mathrm{a}$ & $1.2 \mathrm{~b}$ & $8.8 \mathrm{~b}$ & $85.3 \mathrm{a}$ \\
\hline
\end{tabular}


Table 6. Transmission coefficients for selected materials [42].

\begin{tabular}{cccccc}
\hline $\begin{array}{c}\text { Transmission } \\
\text { Coefficient }\end{array}$ & (No Screen) & Gr 34 & $\begin{array}{c}\text { Control } \\
\text { B and Gr 40 }\end{array}$ & B 40 & B 49 \\
\hline PAR & - & $63.4 \mathrm{a}$ & $57.4 \mathrm{~b}$ & $60.7 \mathrm{~b}$ & $51.3 \mathrm{c}$ \\
NIR & - & $71.2 \mathrm{a}$ & $60.7 \mathrm{c}$ & $60.5 \mathrm{~b}$ & $53.4 \mathrm{c}$ \\
TMB & - & $65.6 \mathrm{a}$ & $58.8 \mathrm{~b}$ & $60.6 \mathrm{~b}$ & $52.2 \mathrm{c}$ \\
B & $1.26 \mathrm{a}$ & $1.16 \mathrm{~b}$ & $1.20 \mathrm{a}$ & $1.26 \mathrm{a}$ & $1.25 \mathrm{a}$ \\
N & $1.30 \mathrm{a}$ & $1.22 \mathrm{~b}$ & $1.26 \mathrm{a}$ & $1.28 \mathrm{a}$ & $1.27 \mathrm{a}$ \\
B:R & $1.04 \mathrm{~b}$ & $1.13 \mathrm{a}$ & $1.04 \mathrm{~b}$ & $1.02 \mathrm{~b}$ & $1.04 \mathrm{~b}$ \\
B:FR & $1.32 \mathrm{a}$ & $1.30 \mathrm{a}$ & $1.25 \mathrm{a}$ & $1.28 \mathrm{a}$ & $1.29 \mathrm{a}$ \\
PAR:TMB & $0.58 \mathrm{a}$ & $0.56 \mathrm{a}$ & $0.57 \mathrm{a}$ & $0.58 \mathrm{a}$ & $0.58 \mathrm{a}$ \\
PAR:NIR & $1.39 \mathrm{a}$ & $1.23 \mathrm{c}$ & $1.31 \mathrm{~b}$ & $1.39 \mathrm{a}$ & $1.35 \mathrm{~b}$ \\
\hline
\end{tabular}

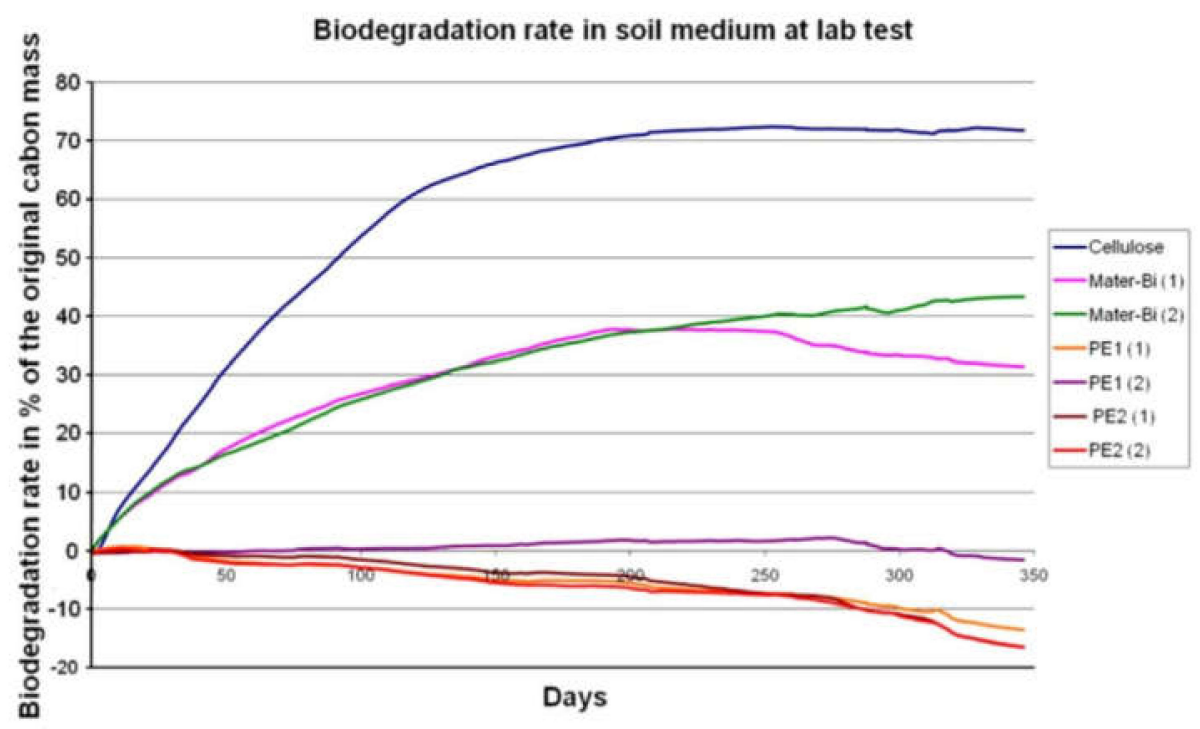

Figure 11. Biodegradation curves for biobased plastics (cellulose) and synthetic polymers (polyethylene) [49].

\subsubsection{Design of Support Structures for Plastic Nets}

Support structures for nets are made of concrete, wood, or metal [4,12]. The application of concrete support is shown in Figure 12. In rare cases, glass support structures are used to support plastic nets. Concrete support structures are better compared to wood and metal from a technical and economic sustainability perspective. The observation is supported by empirical evidence about the durability of wood and metal following exposure to natural elements. First, metallic support structures are prone to corrosion, a process that is exacerbated by water (either from irrigation or rain) [50], chloride ions, and other chemical species that are common in pesticides and organic manure. Alternatively, chemical species, such as sulfate ions, can be generated by microbes, leading to the formation of sulfuric acid [51]. Corrosion increases the risk of material fatigue and failure, which can impact the structural integrity of the greenhouses.

Even though concrete is preferred as a support for plastic nets, acids can weaken hydrated concrete via acid attacks [52]. In addition, modern steel structures are reinforced with steel, which is prone to corrosion despite the integration of corrosion inhibitors [53]. Even though wooden structures are not at risk of corrosion and are environmentally friendly [54], they are attacked by pests and fungi [55]. The most common pests include the longhorn beetle and deathwatch beetle [56]. In addition, the durability of wood is compromised by water. In general, the design of support structures for plastic nets should factor in the risk of corrosion and reduce the progression of corrosion through the galvanization of metallic structures, chemical treatment of wood, and incorporation of inhibitors in 
steel-reinforced concrete. The risk of pest and fungal attack on wooden support structures can be mitigated by using cross-laminated wood [57]. However, there is limited evidence relating to the use of cross-laminated wood in agriculture.

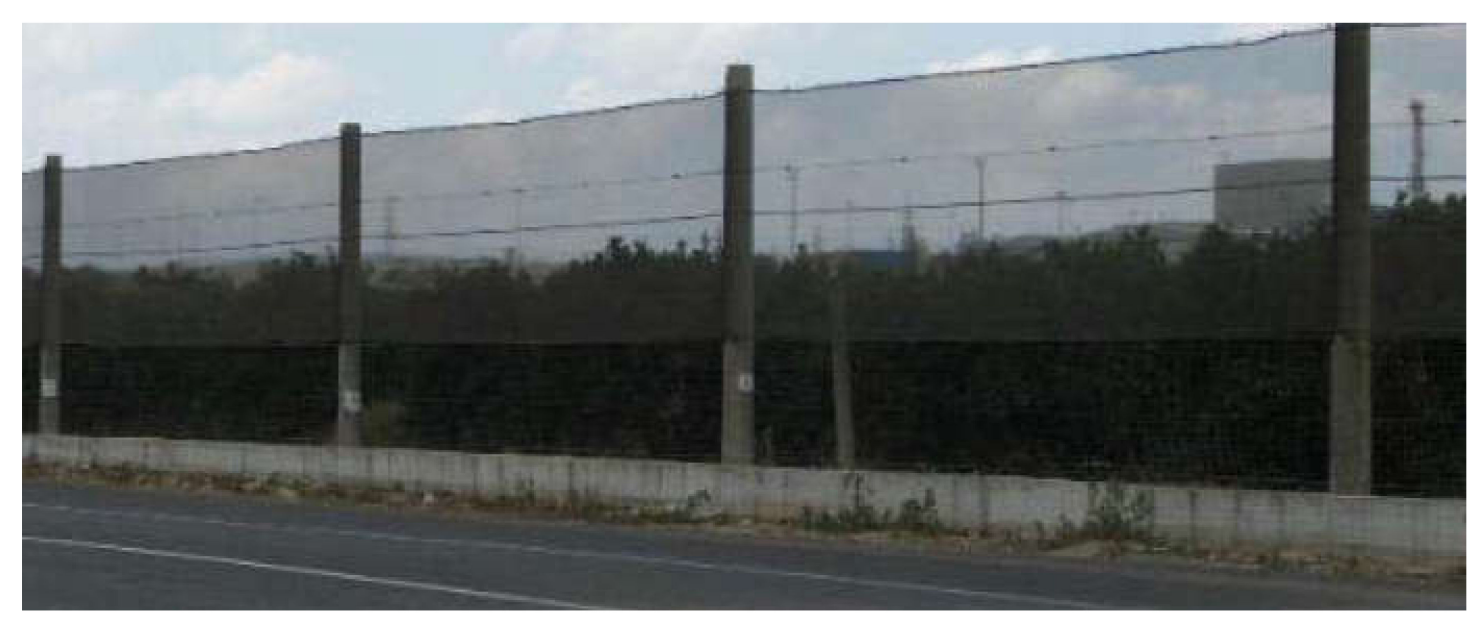

Figure 12. Concrete support structures for plastic nets in farms [11,12].

Beyond the issue of corrosion and pest attacks, cost and the agricultural purpose of the support structures are key criteria in the selection process. Greenhouses used in the cultivation of vegetables are fitted with metallic support structures, even though there is a pronounced risk of corrosion. In addition, wooden support structures are appropriate for vineyards [11]. In the latter case, it could be argued that wooden support poles are preferred because they are environmentally benign and pose no risk to the growth of the vines. Based on the unique trends visualized in Figures 12 and 13, it is evident that the type of plant influences the selection of the materials used to construct the support structures. From a cost sustainability perspective, concrete is affordable over the long term [57] because it does not require constant repairs such as repainting. Even though wood is affordable compared to concrete, it is prone to pest and water attacks. However, further research should be conducted to determine the cost benefits of the materials used as support structures. Current data relating to the cost of steel, wood, and concrete are not specific to agricultural structures. The costs associated with support structures can be controlled through direct installation, which involves placing the nets directly on trees surrounding the farming plots or field borders. The shade structures for table grapes are depicted in Figure 14.

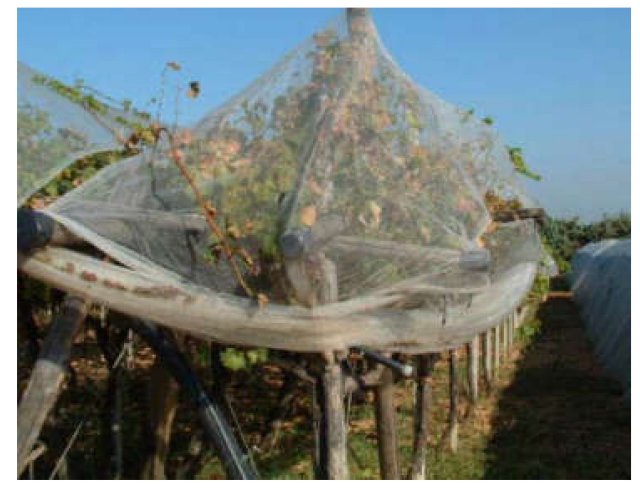

Figure 13. Wooden support structures for plastic nets in a vineyard in Italy [11]. 


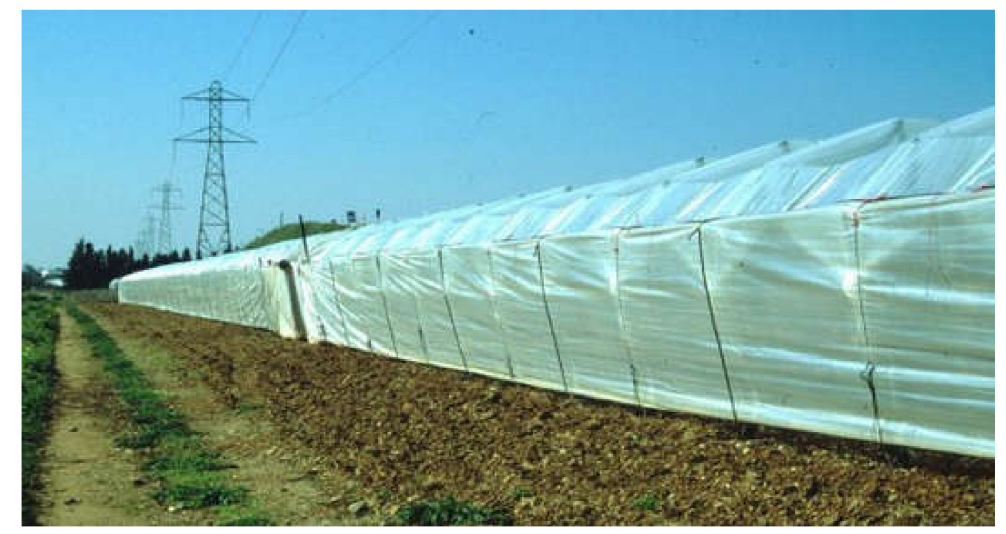

Figure 14. Shade structures for table grapes [58].

\section{Environmental Sustainability and Environmental Impact}

\subsection{Environmental Sustainability of Conventional Polymers}

Sustainability and the environmental impact of plastic nets remains an issue of scholarly interest given the challenges in the manufacturing of biodegradable plastics. From an environmental perspective, biobased plastics are sustainable compared to nonbiobased plastics. The observation is supported by the following facts. Plastic nets and films are the leading sources of agricultural plastic wastes; of the 245,500 kg of agricultural plastic waste collected annually in Barletta, Andria, and Trani in Italy each year, $155,000 \mathrm{~kg}$ of the waste comprises plastic nets and films [45]. Globally, it is estimated that agricultural plastic waste accounts for $2 \%$ of the global waste burden; this is equivalent to 5.2 million tons of waste based on the 2010 statistics [36]. According to the UN Baseline report on plastic waste, the global share of agricultural plastic nets had increased exponentially. For example, in 2016, Canada recorded 45 kilotons of agricultural plastic waste. Nine percent of the agricultural plastics was diverted into other uses, and $5 \%$ was recycled. Based on these statistics, $86 \%$ percent of the agricultural plastic waste was not recycled [59]. The limited rates of recycling show that plastic manufacturers do not have the potential to recycle. However, recycling is less cost-effective. The recycling-related challenges are exacerbated by the lack of affordable and widely available industrial-grade biodegradable plastics. Even though extensive research has been conducted on the subject since the 1990s [60], researchers are yet to find a suitable material due to cost-related factors. Biodegradable plastics are expensive; this is despite the development of novel methods of manufacturing, such as block copolymerization, grafting, and random copolymerization [61].

Beyond the accumulation of waste and lack of alternative materials, the sustainability of plastics can be assessed using a life-cycle assessment (LCA), which tracks the impact of plastics on the environment over the useful life of the product, starting from the sourcing of raw materials, production, distribution, use, and waste management to the site of disposal in line with ISO 14044 and ISO 140140 [62].

The LCA of conventional plastics confirms that these materials have a significant impact on the environment [62]. The impact on the environment is characterized by toxicity (mainly from additives such as phthalates, vinyl chloride (a carcinogen), and plasticizers). Even though vinyl chloride and other toxins in nonbiodegradable plastics could impact human life, if the plastics are used in agricultural applications, the risk is minimal because of the biochemical inertness attributed to the high molecular weight of plastics. However, exposure to excess solar radiation and heat can trigger the release of the toxic chemicals on the farms. Alternatively, toxins such as polycyclic aromatic carbons and dioxins can be released at the end of the useful life of the product. Based on the LCA, nonbiodegradable plastics are not sustainable in agricultural applications-a factor that underscores the need for biobased plastics.

Additional research by Kämpfer et al. [63] and Van Eygen et al. [64] noted that a LCA facilitated the optimization of material recycling at the end of life, which, in turn, has positive environmental 
benefits. However, there was an optimal recycling rate for mixed polymer recycling, after which the hypothesized ecological benefits diminished.

\subsection{Sustainability of Biobased Plastics}

Commercial production of biobased plastics does not match global demand [10], and the production of biobased plastics also involves the addition of nonbiodegradable plastics to enhance the material properties of the former. Other concerns include the lack of an acceptable method for the genetic engineering of microorganisms [44]. The sustainability and environmental concerns are also amplified by the negative effects of biodegradation of products. The materials do not address all environmental threats and the lack of globally accepted standards relating to the production of the biobased plastics and post-use disposal of the plastics. Briassoulis and Dejean [49] noted that biodegradable plastics still pose a threat to the environment and can pollute marine environments. The lightweight nature of these plastics also increases the risk of environmental dispersion to natural habitats. Based on the emerging evidence, the environmental impact of biodegradable plastics is significant, even though biodegradation ensures that the plastic nets are broken down into microscopic particles that are invisible to the naked eye. From a broader perspective, the current technologies used in the production of plastic nets have limited sustainability. However, it is anticipated that future technologies could help to address these issues.

Another sustainability-related concern is the impact of anti-insect plastic nets on the ecology of insects. Živković et al. noted that the movement of spiders and the development of cobwebs was inhibited by anti-insect plastic nets in the apple orchards [26]. The exclusion of spider communities from pineapple orchards compromised nature's way of pest management. Spiders are insect predators. Similarly, agricultural nets limit the movements of birds and disrupt their ecosystems, including food webs. Maas et al. have confirmed that birds are capable of suppressing the growth of arthropods and the formation of moth larvae [27]. The inclusion of anti-insect plastic nets contributes to the proliferation of harmful arthropods. The cost benefits of plastic nets pose new challenges to farmers because protection against common pests requires the elimination of natural insect predators. Considering that the plastic nets cannot provide absolute protection against insects, farmers might still be obliged to use pesticides and fungicides as complementary measures. The use of pesticides is inconsistent with sustainability considerations, which are a central theme in this research. The main concern is whether the support structures for plastic nets can be constructed in a manner that results in minimal disruption to the natural ecosystem, including the movement of birds and spiders; this is an issue that warrants further research attention, beyond the experimental field enclosures reported by Maas et al. [21].

Methods for Assessing the Biodegradability of Biobased Plastics

Various methods have been adopted in the investigation of the biodegradability of plastics. The soil burial test, the most common method, is adopted for the assessment of the rate of biodegradation based on cost-effectiveness. The test involves cutting biobased polymers into small pieces and burying them in the soil to determine the rate of weight loss within a specific time. The weight loss is calculated using Equation (1). The symbols $W_{i}$ and $W_{d}$ denote the initial and final weight, respectively [65]. Significant weight loss within a short time frame denotes high rates of biodegradation and low ecological impact. In brief, the changes in weight are the most important parameters that help to predict the risk of biodegradation.

$$
\text { Weight loss } \%=\frac{W_{i}-W_{d}}{W_{i}} \times 100
$$

\subsection{Cost Factors}

The cost factor should also help to determine the suitability of plastic nets vis-à-vis traditional methods of pest management and the isolated use of pesticides/fungicides. The installation of plastic 
nets is cost-intensive, considering the additional cost of support structures, labor, and periodical maintenance [2]. The installation of the nets on small farms is unstainable without government subsidies or support from nongovernmental organizations (NGOs) that deal with smallholder farmers since smallholder farmers have less disposable income. This is not the case for large farms with sufficient capital resources, however. The cost hypothesis is also informed by the limited lifespan of plastic nets ( $\sim 4$ years) [2].

A comparative analysis of the cost of nonbiodegradable plastic nets versus insecticides shows that the costs are comparable. The cost of biodegradable plastic nets is even higher, considering the special synthetic routes and precursors [12]. Based on the cost factors alone, the installation of anti-insect nets is unsustainable, especially in the case of biodegradable plastic nets. The reason for the spread of plastic nets is the certainty of the production. From another point of view, new and cost-effective methods of producing plastic nets such as electrospinning and extrusion coupled with new sources of precursors might facilitate the development of affordable nets. The proposals for the extension of academic knowledge relating to plastic nets considered in the next section have the potential to also address the problem.

\subsection{Circular Economy Action Plan (CEAP)}

Circular economy action plans (CEAP) are integral for sustainable growth in industrial activities, as evidenced by the development of the EU's CEAP, which is part of the continent-wide green deal. From an abstract perspective, the CEAP is critical for sustainability, considering that it provides a legal mechanism for guiding the development of sustainable products, from the cradle to the grave [66]. On the downside, there is minimal research on the development of circular action plans for plastics derived from agricultural waste. This might impact the sustainability of plastic nets in agricultural applications. The EU CEAP disregards the recycling of plastic waste from agricultural sources. The main emphasis was placed on plastic recycling and biodegradation. In the absence of a plastic-specific CEAP, environmental stakeholders have critiqued the new action plan as inadequate, considering that the European continent has an ecological footprint of 4.7 gha-three times the global average [67]. However, the legal and regulatory changes envisaged in the action plan are progressive and responsive to the present challenges in climate change; such a level of commitment has not been observed in Asia.

\section{Extension of the Considered Literature}

Scholarly research on the sustainability of plastic nets has largely focused on the sustainability aspects of available materials. However, the sustainability of plastic materials extends to all aspects of the lifecycle ("cradle to grave"). Future research should extend the current understanding of the impact of plastic nets on the sustainability of natural biodiversity, including the presence of spiders and birds, which are natural insect predators. Current data have confirmed that the natural activities of spiders, including the formation of cobwebs, are disrupted by anti-insect plastic nets. The impact of surface pesticide application on plastic nets should be investigated in natural settings; this is because the chemical composition of commonly used pesticides has the ability to induce undesired surface doping, leading to the modification of the mechanical properties of plastic and spectral transmissivity, which would, in turn, affect PAR transmission. Another issue that warrants further investigation is the exploration of the utility of electrospinning techniques in the modification of the microstructure of plastic nets vis-à-vis reaction compounding extrusion and optimization of the compostable materials. The lack of green chemistry methods in the development of bio-additives for biodegradable polymers should be considered in upcoming studies. Petri nets should also be explored on a wider scale beyond Japan and the modeling of farm workflow [68]. Based on the established effectiveness of the nets, there is a possibility that digital technologies can regulate meteorological hazards and pests, and complement the function of anti-insect nets. The proposition is validated by the fact that the use of plastic nets is highly mechanical and inefficient, especially in large-scale farming. 


\section{Conclusions}

The demand for sustainable plastic nets in agricultural applications is high because traditional plastics are derived from unsustainable sources (petroleum products). The biochemical inertness and mechanical strength of the plastics are also contingent on the inclusion of carcinogenic compounds such as vinyl chloride and plasticizers. Following the review of the materials used in the development of biodegradable and nonbiodegradable plastic nets, including polyamino acids, polysaccharide derivatives (DS), polyhydroxybutyrate (PHB), polycaprolactone (PCL), polyhydroxylalkanoate (PHA), polylactic acid (PLA), and high-density polyethylene (HDPE), none of the materials have been found to be $100 \%$ sustainable. The biodegradability of the biobased plastics is limited to applications that do not require high tensile strength and flexural strength. In standard applications, the mechanical strength of biobased plastics is reinforced by plasticizers, phthalates, and vinyl chloride, among other additives, which limit the biodegradability of the materials. A reduction in the biodegradability of the material is an issue of concern, considering the absence of a universal biodegradation trigger. The tradeoff between the mechanical properties and environmental properties indicates that new and advanced technologies are required to develop biodegradable plastic nets that are devoid of plasticizers, phthalates, and vinyl chlorides.

Funding: This research received no external funding.

Conflicts of Interest: The authors declare no conflict of interest.

$\begin{array}{ll}\text { Abbreviations } \\ \text { CEAP } & \text { circular economy action plans } \\ \text { DS } & \text { polysaccharide derivatives } \\ \text { ESN } & \text { electrospinning/netting } \\ \text { FT-IR } & \text { Fourier transform-infrared } \\ \text { HDPE } & \text { high-density polyethylene } \\ \text { IPM } & \text { integrated pest management } \\ \text { LCA } & \text { life-cycle assessment } \\ \text { NIR } & \text { near-infrared region } \\ \text { PAR } & \text { photosynthetically active radiation } \\ \text { PCL } & \text { polycaprolactone } \\ \text { PHA } & \text { polyhydroxylalkanoate } \\ \text { PHB } & \text { polyhydroxybutyrate } \\ \text { PLA } & \text { polylactic acid } \\ \text { SCMD } & \text { seasonal crop moisture deficiency } \\ \text { UV } & \text { ultraviolet }\end{array}$

\section{References}

1. Narayan, R. Polymeric Materials from Agricultural Feedstocks; ACS Symposium Series; American Chemical Society: Washington, DC, USA, 1994; pp. 1-27.

2. Vidogbena, F.; Adégbidi, A.; Tossou, R.; Assogba-Komlan, F.; Ngouajio, M.; Martin, T.; Simon, S.; Parrot, L.; Zander, K.K. Control of vegetable pests in Benin Farmers' preferences for eco-friendly nets as an alternative to insecticides. J. Environ. Manag. 2015, 147, 95-107. [CrossRef] [PubMed]

3. Yang, G.; Guo, Z.; Ji, H.; Sheng, J.; Chen, L. Application of insect-proof nets in pesticide-free rice creates an altered microclimate and differential agronomic performance. Peer J. 2018, 6, 1-23. [CrossRef] [PubMed]

4. Castellano, S.; Di Palma, A.; Germinara, G.S.; Lippolis, M.; Starace, G.; Scarascia-mugnozza, G. Experimental Nets for a Protection System against the Vectors of Xylella fastidiosa. Agriculture 2019, 9, 32. [CrossRef]

5. Statuto, D.; Abdel-ghany, A.M.; Starace, G.; Arrigoni, P.; Picuno, P. Comparison of the efficiency of plastic nets for shading greenhouse in different climates. In Proceedings of the International Mid-Term Conference of the Italian Association of Agricultural Engineering, Matera, Italy, 12-13 September 2019. 
6. Wang, X.; Ding, B.; Sun, G.; Wang, M.; Yu, J. Progress in Materials Science Electro-spinning/netting: A strategy for the fabrication of three-dimensional polymer nano-fiber/nets. Prog. Mater. Sci. 2013, 58, 1173-1243. [CrossRef]

7. Briassoulis, D.A.; Mistriotis, A.; Eleftherakis, D. Mechanical behaviour and properties of agricultural nets. Part II: Analysis of the performance of the main categories of agricultural nets. Polym. Test. 2007, 26, 970-984. [CrossRef]

8. Blanco, I.; Loisi, R.V.; Sica, C.; Schettini, E.; Vox, G. Resources, Conservation \& Recycling Agricultural plastic waste mapping using GIS. A case study in Italy. Resour. Conserv. Recycl. 2018, 137, 229-242.

9. Mugnozza, G.S.; Schettini, E.; Loisi, R.V.; Blanco, I.; Vox, G. Georeferencing of agricultural plastic waste. Riv. Stud. Sulla Sostenibilita 2016, 12, 71-82.

10. Abdel-Ghany, A.M.; Al-Helal, I.M. Modeling Approach for Determining Equivalent Optical Constants of Plastic Shading Nets under. Adv. Mater. Sci. Eng. 2012, 2012, 1-8. [CrossRef]

11. Hatti-kaul, R.; Nilsson, L.J.; Zhang, B.; Rehnberg, N.; Lundmark, S. Review Designing Biobased Recyclable Polymers for Plastics. Trends Biotechnol. 2020, 38, 50-67. [CrossRef]

12. Castellano, S.; Russo, G.; Briassoulis, D. Plastic Nets in Agriculture: A General Review of Types and Applications. Appl. Eng. Agric. 2013, 24, 799-808. [CrossRef]

13. Al-Helal, I.M.; Abdel-Ghany, A.M. Responses of plastic shading nets to global and diffuse PAR transfer: Optical properties and evaluation. NJAS Wageningen J. Life Sci. 2010, 57, 125-132. [CrossRef]

14. Rousso, G. La trasmissività radiometrica delle reti in materiale plastico per l'agricoltura. In Proceedings of the L'ingegneria Agraria per lo Sviluppo Sostenibile Dell'area Mediterranea, Catania, Italy, 27-30 June 2005.

15. Vega, J.F.; Martínez-Salazar, J.; Trujillo, M.; Arnal, M.L.; Müller, A.J.; Bredeau, S.; Dubois, P. Rheology, processing, tensile properties, and crystallization of polyethylene/carbon nanotube nanocomposites. Macromolecules 2009, 42, 4719-4727. [CrossRef]

16. Ashby, M.; Shercliff, H.; Cebon, D. Materials Engineering Science and Processing and Design; Elsevier: Amsterdam, Holland, 2009.

17. Callister, W. Materials Science and Engineering: An Introduction; John Wiley and Sons: Hoboken, NJ, USA, 2009.

18. Castellano, S.; Russo, G.; Scarascia, M.G. The influence of construction parameters on radiometric performances of agricultural nets. Acta Hortic. 2006, 718, 283-290. [CrossRef]

19. Mukherjee, A.; Knoch, S.; Tavares, J.R. Use of bio-based polymers in agricultural exclusion nets: A perspective. Biosyst. Eng. 2019, 180, 121-145. [CrossRef]

20. De Simone, S.; Lombardi, F.A.; Paladini, F.; Starace, G.; Sannino, A.; Pollini, M. Development of antibacterial silver treatments on HDPE nets for agriculture. J. Appl. Polym. Sci. 2015, 132, 1-7. [CrossRef]

21. Briassoulis, D.A.; Mistriotis, A.; Eleftherakis, D. Mechanical behaviour and properties of agricultural nets-Part I: Testing methods for agricultural nets. Polym. Test. 2007, 26, 822-832. [CrossRef]

22. Ilić, Z.S.; Milenković, L.; Šunić, L.; Barać, S.; Lezion, R. Effect of shading by coloured nets on yield and fruit quality of sweet pepper. Zemdirbyste-Agric. 2017, 104, 53-62. [CrossRef]

23. Briassoulis, D.; Mistriotis, A. Integrated structural design methodology for agricultural protecting structures covered with nets. Biosyst. Eng. 2010, 105, 205-220. [CrossRef]

24. Dib, H.; Sauphanor, B.; Capowiez, Y. Effect of codling moth exclusion nets on the rosy apple aphid, Dysaphis plantaginea, and its control by natural enemies. Crop. Prot. 2010, 29, 1502-1513. [CrossRef]

25. Maas, B.; Heath, S.; Grass, I.; Cassano, C.; Classen, A.; Faria, D.; Gras, P.; Williams-Guillén, K.; Johnson, M.; Karp, D.S.; et al. Experimental field exclosure of birds and bats in agricultural systems-Methodological insights, potential improvements, and cost-benefit trade-offs. Basic Appl. Ecol. 2019, 35, 1-12. [CrossRef]

26. Živković, P.; Lemic, D.; Samu, F.; Kos, T.; Barić, B. Spider communities affected by exclusion nets. Appl. Ecol. Environ. Res. 2019, 17, 879-887. [CrossRef]

27. Castellano, S.; Mugnozza, G.S.; Russo, G.; Briassoulis, D.; Mistriotis, A.; Hemming, S.; Waaijenberg, D. Design and Use Criteria of Netting Systems for Agricultural Production in Italy. J. Agric. Eng. 2008, 39, 31-42. [CrossRef]

28. Legarrea, S.; Karnieli, A.; Fereres, A.; Weintraub, P.G. Comparison of UV-absorbing Nets in Pepper Crops: Spectral Properties, Effects on Plants and Pest Control. Photochem. Photobiol. 2010, 86, 324-330. [CrossRef] [PubMed] 
29. Black-Solis, J.; Ventura-Aguilar, R.I.; Correa-Pacheco, Z.; Corona-Rangel, M.L.; Bautista-Baños, S. Preharvest use of biodegradable polyester nets added with cinnamon essential oil and the effect on the storage life of tomatoes and the development of Alternaria alternate. Sci. Hortic. (Amsterdam) 2019, 245, 65-73. [CrossRef]

30. Castellano, S.; Hemming, S.; Russo, G.; Mohammadkkhani, V.; Swinkels, G.J.; Scarascia, M.G. Radiometric properties of agricultural permeable coverings. J. Agric. Eng. 2010, 41, 1-12.

31. Hemming, S.; Swinkels, G.L.A.M.; Castellano, S.; Russo, G.; Scarascia-Mugnozza, G. Numerical model to estimate the radiometric performance of net covered structures (AGRONETS). In Proceedings of the AgEng2008 Agricultural and Biosystems Engineering for a Sustainable World, Crete, Greece, 23-25 June 2008.

32. Ilić, S.Z.; Milenković, L.; Dimitrijević, A.; Stanojević, L.; Cvetković, D.; Kevrešan, Ž.; Fallik, E.; Mastilović, J. Light modification by color nets improve quality of lettuce from summer production. Sci. Hortic. 2017, 226, 389-397. [CrossRef]

33. Lekala, C. Cultivar-specific responses in red sweet peppers grown under shade nets and controlled-temperature plastic tunnel environment on antioxidant constituents at harvest. Food Chem. 2019, 275, 85-94. [CrossRef]

34. Boini, A.; Bresilla, K.; Perulli, G.D.; Manfrini, L.; Grappadelli, L.C.; Morandi, B. Photoselective nets impact apple sap flow and fruit growth. Agric. Water Manag. 2019, 226. [CrossRef]

35. Abdel-Ghany, A.M.; Al-Helal, I.M. Analysis of solar radiation transfer: A method to estimate the porosity of a plastic shading net. Energy Convers. Manag. 2011, 52, 1755-1762. [CrossRef]

36. Abdel-ghany, A.M. Solar Energy Materials \& Solar Cells Characterization of solar radiation transmission through plastic shading nets. Sol. Energy Mater. Sol. Cells 2010, 94, 1371-1378.

37. Milenkovi, L. Effects of the modification of light intensity by color shade nets on yield and quality of tomato fruits. Sci. Hortic. (Amsterdam) 2012, 139, 90-95.

38. Schettini, E.; De Salvador, F.R.; Scarascia Mugnozza, G.S.; Vox, G. Evaluation of coloured nets in peach protected cultivation. Acta Hortic. 2011, 893, 235-242. [CrossRef]

39. Sica, C.; Picuno, P. Spectro-radiometrical characterization of plastic nets for protected cultivation. Acta Hortic. 2008, 801, 245-252. [CrossRef]

40. Castellano, S.; Hemming, S.; Russo, G. The Influence of Colour on Radiometric Performances of Agricultural Nets. Acta Hortic. 2008, 801, 227-236. [CrossRef]

41. Dáder, B.; Legarrea, S.; Moreno, A.; Plaza, M.; Fereres, A. Control of insect vectors and plant viruses in protected crops by novel pyrethroid-treated. Pest. Manag. Sci. 2014, 71, 1397-1406. [CrossRef]

42. Castellano, S.; Starace, G.; De Pascalis, L.; Lippolis, M.; Scarascia, G. ScienceDirect Test results and empirical correlations to account for air permeability of agricultural nets. Biosyst. Eng. 2016, 150, 131-141. [CrossRef]

43. Rudnik, E.; Briassoulis, D. Comparative Biodegradation in Soil Behaviour of two Biodegradable Polymers Based on Renewable Resources. J. Polym. Environ. 2011, 19, 18-39. [CrossRef]

44. Iwata, T. Biodegradable and bio-based polymers: Future prospects of eco-friendly plastics. Angew. Chemie Int. Ed. 2015, 54, 3210-3215. [CrossRef]

45. Vox, G.; Viviana, R.; Blanco, I.; Scarascia, G. Mapping of agriculture plastic waste. Agric. Agric. Sci. Procedia 2016, 8, 583-591. [CrossRef]

46. Lorcks, J. Properties and applications of compostable starch-based plastic material. Polym. Degrad. Stab. 1998, 59, 245-249. [CrossRef]

47. Briassoulis, D.; Hiskakis, M.; Babou, E.; Antiohos, S.K.; Papadi, C. Experimental investigation of the quality characteristics of agricultural plastic wastes regarding their recycling and energy recovery potential. Waste Manag. 2012, 32, 1075-1090. [CrossRef] [PubMed]

48. Briassoulis, D.; Hiskakis, M.; Babou, E. Technical specifications for mechanical recycling of agricultural plastic waste. Waste Manag. 2013, 33, 1516-1530. [CrossRef] [PubMed]

49. Briassoulis, D.; Dejean, C. Critical Review of Norms and Standards for Biodegradable Agricultural Plastics Part I. Biodegradation in Soil. J. Polym. Environ. 2010, 18, 384-400. [CrossRef]

50. Roberge, P.R. Corrosion Engineering: Principles and Practice; McGraw Hill: New York, NY, USA, 2009.

51. Huber, B.; Hilbig, H.; Drewes, J.E.; Müller, E. Cement and Concrete Research Evaluation of concrete corrosion after short- and long-term exposure to chemically and microbially generated sulfuric acid. Cem. Concr. Res. 2017, 94, 36-48. [CrossRef]

52. Allahverdi, A.; Skvara, F. Acidic corrosion of hydrated cement based materials-Part 1. Ceram. Silikáty 2000, 3, 114-120. 
53. Söylev, T.A.; Richardson, M.G. Corrosion inhibitors for steel in concrete: State-of-the-art report. Constr. Build. Mater. 2008, 22, 609-622. [CrossRef]

54. Cuce, E.; Cuce, P.M.; Wood, C.J.; Riffat, S.B. Optimizing insulation thickness and analysing environmental impacts of aerogel-based thermal superinsulation in buildings. Energy Build. 2014, 77, 28-39. [CrossRef]

55. Marin, R.A.; Carreira, X.C.; Ferna, M.E. Durability of timber structures in agricultural and livestock buildings. Biosyst. Eng. 2009, 104, 152-160. [CrossRef]

56. De Belie, N.; Richardson, M.; Braam, C.R.; Svennerstedt, B.; Lenehan, J.J.; Sonck, B. Durability of Building Materials and Components in the Agricultural Environment: Part I. Agric. Environ. Timber Struct. 2000, 225-241.

57. Mallo, M.F.L.; Espinoza, O. Cross-Laminated Timber vs. In Concrete/steel: Cost comparison using a case study. In Proceedings of the 2016 World Conference on Timber Engineering, WCTE 2016, Vienna, Austria, 22-25 August 2016; pp. 1-8.

58. Novello, V.; de Palma, L. Growing grapes under cover. Acta Hortic. 2008, 785, 353-362. [CrossRef]

59. United Nations-UNEP. Baseline Report on Plastic Waste; UNEP: New York, NY, USA, 2020.

60. Lenz, R.W. Biodegradable Polymers and Plastics in Japan: Research, Development, and Applications; Japanese Technology Evaluation Center: Tokyo, Japan, 1995; pp. 1-45.

61. Vroman, I.; Tighzert, L. Biodegradable Polymers. Materials 2009, 2, 307-344. [CrossRef]

62. Lackner, M. Bioplastics - Biobased plastics as renewable and/or biodegradable alternatives to petroplastics. In Encyclopedia of Chemical Technology; Othmer, K., Ed.; Wiley Publishing, Inc.: Hoboken, NJ, USA, 2015.

63. Kämpfer, C. Life cycle assessment and sustainable engineering in the context of near net shape grown components: Striving towards a sustainable way of future production. Environ. Sci. Eur. 2017, 29, 1-6. [CrossRef]

64. Van Eygen, E.; Laner, D.; Fellner, J. Integrating High-Resolution Material Flow Data into the Environmental Assessment of Waste Management System Scenarios: The Case of Plastic Packaging in Austria. Environ. Sci. Technol. 2018, 52, 10934-10945. [CrossRef] [PubMed]

65. Bashir, A.; Jabeen, S.; Gull, N.; Islam, A.; Sultan, M. Macromolecules Co-concentration effect of silane with natural extract on biodegradable polymeric films for food packaging. Int. J. Biol. Macromol. 2018, 106, 351-359. [CrossRef] [PubMed]

66. European Commission. Closing the Loop-An EU Action Plan for the Circular Economy. 2015. Available online: https://eur-lex.europa.eu/legal-content/EN/TXT/?uri=CELEX\%3A52015DC0614 (accessed on 23 April 2020).

67. Pantzar, M.; Suljada, T. An Analysis of the New EU Circular Economy Action Plan, Institute for European Environmental Policy. 2020. Available online: https://ieep.eu/publications/an-analysis-of-the-new-eucircular-economy-action-plan (accessed on 23 April 2020).

68. Guan, S.; Nakamura, M.; Shikanai, T.; Okazaki, T. Hybrid Petri nets modeling for farm work flow. Comput. Electron. Agric. 2007, 2, 149-158. [CrossRef]

(C) 2020 by the author. Licensee MDPI, Basel, Switzerland. This article is an open access article distributed under the terms and conditions of the Creative Commons Attribution (CC BY) license (http://creativecommons.org/licenses/by/4.0/). 